\title{
1
}

\section{Social Protection in the Global South: An Ideational and Historical Approach}

\author{
Lutz Leisering
}

\section{Towards a New Approach to Analysing Social Policy in the Global South ${ }^{1}$}

The centres of gravity in the world are shifting. Some of the countries formerly referred to as developing or Third World countries are emerging as global players in terms of their share of the global economy, world population, and international political power. These shifts are changing the face of global society in many ways. As regards social welfare, we ${ }^{2}$ cannot simply expect that the Northern concept of the "welfare state" will "travel" to the Global South. Gough and Therborn (2010: 711) posit

\footnotetext{
${ }^{1}$ I thank Sony Pellissery, Jeremy Seekings, Marianne Ulriksen, and Timotheus Brunotte for comments on an earlier draft. I am also indebted to Tobias Böger and Shih-Jiunn Shi for advice. Timotheus Brunotte helped to collect the data on the four countries.

2 "We" in the introduction refers to views discussed and shared by the contributors of the volume, whereas "I" refers to the author's views and arguments.
}

\section{Leisering $(\bowtie)$}

Department of Sociology, Bielefeld University, Bielefeld, Germany e-mail: lutz.leisering@uni-bielefeld.de 
that the "developmental paths of European welfare states are not likely to be repeated" elsewhere. Some writers even question the possible spread of formal social protection programmes in the South on cultural grounds (Rieger and Leibfried 2004; Walker and Wong 1996). The global future of public welfare will be shaped by the Global South. At present, the majority of the population in the South lack formal social protection. What ideas and institutional models of public welfare are developing in the Global South?

"If we want to know where to go, we have to know where we came from" (Kaufmann 2012: 1). Accordingly, this volume investigates the evolution of social protection ideas and policies in four key middleincome countries-Brazil, China, India, and South Africa-from the 1920 s to the present day. We seek to trace the formative ideas and models that have inspired key actors in these four countries and defined institutional paths in order to "understand" Southern welfare. We begin with the early twentieth century, because, as we argue, the history of social policy in the South had already started before World War II (Midgley 1984: 1). In all four countries, intellectuals debated the use of social insurance as a "modern" kind of social welfare as early as the 1920s, and the first social legislation was passed.

The post-war welfare state in Europe was part of the rise of "democratic welfare capitalism" - the mixed or "hyphenated society" (Marshall 1981a). Today, these countries spend 20-35 per cent of their gross domestic product (GDP) on monetary transfers and social services. In the Global South, other developments prevailed during those decades, such as struggles for political and/or economic independence, decolonialisation, nation-building, and "development". State-provided social protection mostly took a back seat, and state social spending has continued to be low through the present day, making up regional averages of 5-13 per cent of GDP with outliers around 2 and 20 per cent. Only selected groups were covered. However, since the late 1990s, social protection policy has moved higher up on the agendas of many Southern governments and international development organisations. Social cash transfers to the poor mushroomed in the South in the 2000s and 2010s and provided a modicum of social protection to sections of the population that had previously been excluded. Brazil, China, and South Africa 
all pioneered social cash transfer programmes (Barrientos 2013; Leisering 2019), and the Indian Mahatma Gandhi National Rural Employment Guarantee Act has also received much attention in the global development community.

These recent developments have been much discussed in global political and scholarly arenas, but the early history of social policy in the Global South is only beginning to be researched-unlike the evolution of the Northern welfare state, which scholars have comprehensively analysed both in empirical and theoretical terms (comparative studies include Rimlinger 1971; Flora and Heidenheimer 1981; Alber 1982; Lindert 2004a, b). A whole continent of early social policy in the Global South awaits discovery.

This volume contributes to the filling of three research gaps by adopting a historical, ideational, and source-based approach.

First, although research on formal social protection programmes and policies in the South has cropped up since the mid-2000s, this literature has a presentist bias, focusing on changes since the 1990s and even more on changes since the 2000s, when "social protection" - a term which tends to supersede the older term "social security"- became a new paradigm for development policy (Holzmann et al. 2003). The global social policy literature barely takes notice of the small but growing body of research on Southern social policy during colonial and early post-colonial times. ${ }^{3}$ Similarly, in the historical memory of Southern societies and general historical studies of the South, social policy does not normally figure in a major way. To understand and explain Southern welfare policies, therefore, this volume pursues a historical approach that traces the development of social protection ideas and policies in the four middle-income countries back to the 1920s.

The historical perspective implies attention to timing, critical junctures, founding moments, and historical "paths" (Mahoney and Thelen 2015). Lustick (1996) warns against a possible bias created when social

\footnotetext{
${ }^{3}$ However, see Midgley and Piachaud (2011), Seekings (2007a, b, 2011, 2013, 2016), Lewis and Lloyd-Sherlock (2009), Lindner (2014), Hu and Manning (2010), and Schmitt et al. (2015) (the latter two on the global history of social insurance), Schmitt (2015) on colonies, Collier and Messick (1975) on the historical sequences of social security adoption worldwide, Hort and Kuhnle (2000) on adoption sequences in Southeast Asia. See also the pioneering study by Midgley (1984).
} 
scientists draw selectively on extant historiographical studies. Social scientists have to be careful, especially if there is a rich and long tradition of historiographical studies in the field under investigation rather than an undisputed "historical record" (Lustick 1996: 615). However, in the field of social protection, such tradition is absent, and the contributors to this volume themselves act as historians. In fact, two of the contributors are historians (Hu and Ahuja), and the author of two other chapters (Seekings) has a record of primary source-based historical studies.

Historical and comparative small $\mathrm{n}$ research (i.e. with few cases) has "played a central role in driving the agenda of research on welfare states" (Amenta and Hicks 2010: 118) and seems promising also for the South. Concentrating on a few cases enables in-depth primary research, and the comparative and historical perspectives may also contribute to theorising social policy by revealing the varieties of social policies. Even in research on the Global North, comparative qualitative historical studies are rare, especially comprehensive studies of welfare states rather than particular programmes (Rimlinger 1971, Pinker 1979, de Swaan 1988, Kaufmann 2013a; partially quantitative: Flora and Alber 1981).

Second, in the Weberian tradition, this volume focuses on the ideas that underpin social policies. While most policy studies centre on the interests of and struggles between actors, such as political parties, business, and workers, and analyse, for example, corporatism, cross-class alliances, political settlements (for the Global South, see Lavers and Hickey 2016), and political alignments (Haggard and Kaufman 2008), we examine the ideas that underlie social policies and, from a constructivist point of view, even co-define interests. By "ideas" we not only and not even primarily mean broad ideologies and values, such as liberalism, social democracy, or social justice, but complex, multi-layered configurations of ideas that encompass broad ideas as well as more specific normative and cognitive ideas: beliefs, attitudes, perceptions, theories, and images relating to welfare institutions, social problems, statehood, and visions of society. In the Introduction, I develop a multi-layered model of social ideas-the "onion skin model"-which has the social question as the pivot. Raising the "social question" means that a society recognises social issues in a generalised way as a key concern of society to be addressed by 
the state, linked to a call for political remedies. The underlying assumption is that the state is responsible for individual welfare.

By focusing on ideas, the volume also seeks to contribute to a theory of "social policy in development contexts" (UNRISD 2001; Gough et al. 2004), which is a desideratum (for a call for theory, see, e.g. Surender 2013: 29). Most studies on global social policy are reports by or for international organisations or case studies, and/or have a descriptive character and practical concerns or are interspersed with advocacy.

This introduction tackles the theorisation of Southern welfare in four steps (next four sections): (a) I start by sketching out a methodological framework, a constructivist sociology of knowledge approach, which brings in ideas in a constitutive way akin to constructivist and discursive institutionalism. The next three steps relate to substantive theorisation. (b) I discuss four basic strategies for theorising Southern welfare, and I opt for starting from Northern welfare state theories to be modified for a globally applicable theory. (c) I draw on the rich tradition of explanatory theories of Northern welfare state development and specify modifications. (d) Eventually, I develop a new, multi-layered model of social ideas, visualised as an onion with layers - therefore called the "onion skin model". The model combines elements from the (small) tradition of ideational welfare state theories.

Third, the volume goes back to historical sources, that is, to original documents like parliamentary records and manifestos that reflect the views of contemporary actors. The idea is to give a voice to domestic elites and social movements, rather than imposing preconceived concepts from Northern welfare state research on Southern societies. This volume's authors come from the countries under investigation or have roots in them, which helps the authors to read and contextualise contemporary documents. Such contributions are significant because systematic recourse to documents is not widespread in the social policy literature.

We assume that over the last hundred years, social policy, by and large, has expanded in many Southern countries and, sometimes linked, gained prominence on the agendas of international organisations. We seek to trace and partially explain this process in our four countries. Our general research question is: What changes in ideas among elites and the citizenry 
underpinned — or inhibited — the rise of social protection policies? When did basic "social" categories and terms like "social problems" and "social security" emerge? What contestations accompanied the evolution of social protection? More specifically we inquire:

- Was a "social question" raised, that is, did social issues become a key concern for state and society? How was the social question posed, that is, what was defined as the overarching problem that social policy should tackle?

- What other concerns, like independence, nation-building, or economic development, competed with, eclipsed, or propelled the social question?

- What institutional models of social protection were advanced?

- What notions of the state prevailed in public discourses?

- Did external ideas-from other countries or international organisations_-impact domestic policies?

The concluding chapter of the volume discusses the findings of the country-centric chapters in comparative and theoretical terms.

We chose Brazil, China, India, and South Africa because in all four countries public welfare programmes have expanded since the 1990s (Tillin and Duckett 2017; India the least), and they cover all nonEuropean continents except Australia and the Pacific. The history of the four countries includes democratic, semi-democratic, and authoritarian regimes. Surprisingly, scholars have rarely analysed social policy in the four countries comparatively, and not with a focus on ideas or from a historical perspective. Tillin and Duckett (2017) focus on politics, OECD (2010), Rodgers (2013), and Fakier and Ehmke (2014) on employment-related issues, and practical concerns for "extending social security" drove the study by the International Social Security Association (ISSA 2013). This volume is closest to Midgley and Piachaud (2013) who focus on institutions (of social protection). Their volume provides valuable descriptions of the institutional arrangements for social protection in the four countries, including broad contexts and history. They do not take the spread of social protection for granted (Piachaud and Midgley 2013: 276f.) and address the challenge of aligning welfare goals with 
economic and other goals (Midgley 2013: 17-20). They also address ideas, via policy goals. While all this has an affinity to the approach taken in our volume, Midgley and Piachaud's research is not conceived as a source-based and theory-driven study of ideas.

The volume by Breman et al. (2019a) addresses the social question in selected countries from all world regions, including our four countries, but is primarily concerned with objective socio-economic conditions rather than the ways that politics and society articulated these conditions as the social question. The focus is on labour issues and class actors. In this Marxist approach, ideas only figure in broad terms as class-related ideologies, especially neoliberalism and social democracy. Breman et al. (2019b: 245, 249) diagnose a recent global "return of the social question" which, however, as they argue, powerful global actors currently seek to limit and prevent.

Why social protection? In Global North countries, social protection is the key focus of the welfare state and accounts for the bulk of social spending: income maintenance and health are the biggest items. Almost everyone is covered, and social protection has increasingly shaped people's lives in these countries. But in many countries of the Global South, social protection is thin.

We chose the term "social protection" for the title of this volume because there is not one overarching term that was used throughout the last hundred years and in all countries, and, furthermore, "social protection" has come to complement or even replace the term social security in international debates since around the year 2000. "Social security" is the older term, but was not used throughout the world and past either. The International Labour Organization (ILO), the original champion of the concept of "social security", switched to using "social protection" in the second edition of its "World Social Protection Report" (ILO 2017). Not using the term "social security" in our title also avoids references to US usage, which is largely restricted to old-age security.

The meaning of the term "social security" varies between authors, as does the meaning of "social protection". "Social protection" often covers (contributory) social insurance, non-contributory provisions and allowances, social assistance, and labour rights, whereas authors tend to more narrowly define "social security" as mainly social insurance and social 
assistance. "Social security" is a term with a considerable history, encapsulating much of the history of social policy (Petersen and Béland 2014: 298). If and how the term "social security" emerged and how it was defined is part of the studies presented in this volume. In the concluding chapter of this volume, I will discuss the term and idea of social security in greater detail. The volume focuses on what nowadays is mostly viewed as "social security"; labour rights that relate to the workplace and to collective action are mostly excluded. Health is included regarding entitlements to medical services, through social insurance, but not regarding the provision of services.

The Introduction focuses on theorising, in four steps as explained above (next four sections). After the theoretical sections, there is a section that provides basic data on the history, the international context, and the socio-economic condition of the four countries. The Introduction concludes with a section that summarises the volume's chapters.

\section{Ideas: A Constructivist Sociology of Knowledge Approach}

"Interests (material and ideal), not ideas, directly determine people's actions. But: the 'world views' created by 'ideas' have, like a switchboard operator, often set the future course according to which the dynamics of interests have conditioned action" (Max Weber, translated by Ryan DeLaney; in Lepsius 2017: 23). ${ }^{4}$ In this famous quote, Max Weber identifies interests and ideas as the key forces of social action but places a special emphasis on ideas. Ideas provide legitimacy for interests and mobilise people. Yet more fundamentally, ideas may even co-constitute-shape, define, and redefine - interests in the first place. In this sense, the contributions to this volume do not aim to provide histories of ideas as such. Rather, they are about ideas that matter in politics and how they matter.

\footnotetext{
${ }^{4}$ German original: "Interessen (materielle und ideelle), nicht: Ideen, beherrschen unmittelbar das Handeln der Menschen. Aber: die ,Weltbilder', welche durch ,Ideen' geschaffen wurden, haben sehr oft als Weichensteller die Bahnen bestimmt, in denen die Dynamik der Interessen das Handeln fortbewegte" (Weber 1978: 252).
} 
To grasp the impact of ideas, an in-depth analysis of ideas is required. Lepsius (2017: 23-25, 33), a major Weber scholar, writes on Weber:

"His body of work is pervaded with the effort to analyze the intertwining of interests and ideas ... ideas need to be unfolded in their cognitive structure in order to recognize the relevance for action contained within the ideas' characteristics... . Only when this is done can their actual importance for the actions of individuals and collectives and for institutionalization processes be identified. As long as ideas are described in general terms and their internal structure is not determined, their consequences for social action also cannot be exactly specified, and social behavior cannot be attributed to them.... this agenda does not imply an idealistic philosophy of history... . the focus here is on the empirically demonstrable attribution of social phenomena to cultural elements... . Interests and ideas ... describe two analytical perspectives ... [that] must be viewed in their complementarity."

Accordingly, our theoretical aim is to model the cognitive structure of the ideas that constitute the field of social policy. To this end, I have developed a multi-layered ideational model, the "onion skin model", which is reflected in the chapters of this volume.

References to ideas are common in the Northern welfare state literature, especially normative approaches that define social policy through values such as equality, solidarity, social justice, or security. Political economy approaches also take into account ideas by distinguishing class-based ideologies_-liberalism, conservatism, social democracy - that are viewed as characterising different welfare regimes with social democracy as the hallmark of fully fledged welfare statism (Esping-Andersen 1990). In comparative empirical research, these ideologies figure as the doctrines of the political parties in power. Values and ideologies obviously matter in social policy development, but it is more specific ideas that shape policies and the problems addressed by them. In the research on developed welfare states, the social construction of the problems addressed is mostly taken for granted and left unexplored like the definition of the social risks that social protection programmes address (explicitly so, e.g. by Baldwin 1990: 12, FN 10). However, in a historical analysis of the rise of social policy, we need to trace when and how such categories were constructed in the first place. 
The ideational or discursive turn in policy analysis has also drawn attention to ideas ${ }^{5}$ but mostly refers to ideas in particular policy processes, like explaining the introduction of a certain welfare programme, rather than to the ideational foundations of social policy in the history of a country. However, we can use Hall's (1993) concepts of "policy paradigms" and "paradigm shifts" to detect more far-reaching ideational changes in policies. Development economics is more interested in issues of finance and policy implementation than in ideas. When ideas are systematically addressed, this is done by way of normative theory, which discusses, for example, how poverty should be defined and social justice be conceived and what financial allocation is optimal (e.g. Barrientos 2013), rather than investigating the ideas held by actors. However, social policy is not only about financial flows, redistribution, and administration but also about ideas and social recognition (Kaufmann 2012: 251, 255-256; 2015: 12-18).

Our analysis of ideas is based on five assumptions.

First, ideas matter for social policy. Ideas may imbue actors with a purpose beyond simple considerations of utility and material interests. "Whenever affective orientations can be collectively mobilised towards certain ideas, as recently happened with regard to peace and environmental concerns or female emancipation, there is a chance for new, powerful elements of normative culture" (Kaufmann 1991: 23; transl. L.L.).

Second, whereas recent ideational approaches in policy research mostly take ideas as a distinct factor besides other factors (Fischer 2003; overview von Gliszczynski 2015: ch. 1), exerting influence only under certain circumstances of, for example, instability and crisis (Blyth 2002; Béland 2009; Campbell 2002), we adopt a constructivist sociology of knowledge approach based on the assumption that ideas and knowledge pervade politics and thereby co-constitute interests, institutions, and policies (Nullmeier 2003). The challenge, therefore, is to analyse how contemporary actors constructed interests, institutions, and policies. The constructivist perspective also helps us avoid Eurocentrism.

\footnotetext{
${ }^{5}$ Ideational approaches to policy research emerged in the North in the 1990s. For a discussion, see von Gliszczynski (2015: 8-13), for proponents see V.A. Schmidt (2008, "discursive institutionalism”) and Béland (2009). Early proponents include Heclo (1974, see especially 305-306) and Hall (1993).
} 
Third, from the perspective of interpretive sociology, we emphasise that ideas are subject to interpretations by actors, with interpretations varying across time and space. In this way, we extend the constructivist approach to apply to ideas. For example, basic ideas like human rights, "development", "inclusion", and "poverty" can be interpreted in very different ways, leading to different policies.

Fourth, the focus on "ideas" is not only about the broad ideologies and values that are at the forefront of social policy debates but also about more specific normative and cognitive categories that constitute policymaking and institution building. Substantial social policy is predicated on the emergence of specific "social" categories or "social knowledge" in politics and society (Rueschemeyer and Skocpol 1996). Pereira and Bertholini (2017), for example, find that the belief in "social inclusion" cuts across political ideologies in post-1988 Brazil. The historical rise of social protection relies on the formation of "social" concepts that relate to social problems, such as poverty or disability, to ideational models of welfare programmes like "social security" or "social insurance", or to statehood. Epistemic communities, political parties, and social policy communities may entrench the emerging social categories in policymaking. We can conceptualise the influx of "social" concepts and categories as a "socialisation" of politics (Leisering 2019: 325f.). Socialisation may include the rise of new ideas and actors as well as a social specification of older and more general ideas (like Christian thought or Confucianism) and actors.

Fifth, the ideas articulated early on in a country's development may create a path for future development. This is why ideas matter beyond single policy acts and why a historical-ideational approach can help us to understand present-day social policy. Ideas-especially how the "social question" is articulated early on-shape institution building in the field of public welfare (Kaufmann 2013a: 32f.). For instance, defining the social question as the workers' question is likely to lead to the introduction of employment-based contributory social insurance programmes as the mainstay of a country's social protection arrangement as it did in nineteenth-century Germany under Bismarck. Through epistemic and policy communities that operate as the bearers of ideas, social ideas may acquire a degree of relative autonomy and independent dynamics. 
Path-dependent development does not mean determination, but, instead, indicates the social costs of changing an institutional path. A path may be transformed, for example, by a new interpretation of the idea that defines the path, such as the idea of "social insurance".

All in all, our approach incorporates elements from historical, discursive, and constructivist institutionalism (Peters 2012; for historical institutionalism in social policy research see Rueschemeyer and Skocpol 1996).

There is a vast literature that focuses on causes and effects of welfare states, but only a few scholars have investigated the nature of the welfare state as an ideational and cultural project. ${ }^{6}$ The ideational and cultural strand of welfare state research is part of the pluralist WeberianDurkheimian tradition, which conceives of social policy as a response to broad processes of modernisation rather than merely a response to capitalism, as assumed in the Marxist and political economy traditions (see the analysis of theoretical approaches by Alber 1982: 73-88 and Pinker 1971: ch. 1). From a pluralist angle, a broad range of ideas beyond classbased ideologies come into view. The pluralist tradition represents an almost-forgotten, mostly sociological approach to the study of the welfare state and has been eclipsed by political economy approaches. The ideational approach in this volume builds on the pluralist strand of research.

Assuming that the spread of public welfare is predicated on far-reaching changes in collective mindsets, the pluralist authors take a historical approach to welfare state analysis. Thomas Humphrey Marshall (1950) analyses the rise of the idea and institutions of equality in the wake of state-building, focusing on social rights and their societal requisites, which includes a "welfare consciousness" among citizens and elites (Marshall 1981b: 89) and the formation of social professions. Although Marshall is the most frequently quoted theorist of the welfare state, it is

\footnotetext{
${ }^{6}$ For the UK, see Marshall (1950, 1981a, b) and Pinker (1979); for the United States, see Janowitz (1976) and Heclo (1995); for the Netherlands, de Swaan (1988) and van Kersbergen (1995); for Germany, Kaufmann (1991, 1997, 2013a, 2012), Nullmeier (2000), Zacher (2013), and Achinger (1979, first published 1958); for India, see Singh (2015a, b); and for social anthropology and Southeast Asia, see von Benda-Beckmann and von Benda-Beckmann (1994). Lessenich (2003) and Béland and Petersen (2014) explore basic concepts of the welfare state and of social policy, respectively. John W. Meyer's (2009) neo-institutionalist theory of world society posits the existence of a "world culture" that took off in the 1940s and includes ideas of social progress, a growing awareness of social problems, and statehood.
} 
rarely acknowledged that his work follows a constructivist methodology, which differs from mainstream research (see the reconstruction in Leisering 2019: 51-56).

Abram de Swaan (1988) analyses the rise of a "social conscience" in Western societies and related new configurations of knowledge among citizens and elites, such as professionalisation and the "protoprofessionalisation" of the citizens. Franz-Xaver Kaufmann (2015) conceives of the welfare state as a demanding and historically unlikely "cultural idea"7 imbued with national "intellectual traditions", even "autonomous cosmologies... It begins with the terms that are used and the associations they bear, carries over into different fundamental notions about the relationship between state and society, and culminates in different social policy ideals and the articulation of the problems these entail" (Kaufmann 2013a: 33).

In this cultural sense, Kaufmann (2013c: 31) classifies the United States as "capitalism" rather than a "welfare state". Robert Pinker (1979) argues that the notions of social obligations among citizens precede the notion of rights and do not necessarily support state-provided welfare. It is the "subtle interplay of loyalties which characterize people's notions of welfare obligation and entitlement" (Pinker 1979: 10), and allegiance to the state is only one of several nested socio-spatial loyalties, which include family, local community, and international community.

\section{Strategies for Theorising Southern Welfare}

Studies on formal social security in the South are relatively recent. Well into the 1990s, development scholars equated "social security" in the South with informal relationships between kin and within small communities (e.g. Lachenmann 1997). The bulk of the research on state-led welfare was case studies, often of a descriptive nature (however, see Midgley 1984 and von Benda-Beckmann and von Benda-Beckmann

\footnotetext{
${ }^{7}$ For cultural theories of social policy, see also Pfau-Effinger (2005, 2009), Ullrich (2003), and van Oorschot et al. (2008). For religious roots see van Kersbergen (1995), van Kersbergen and Manow (2009), and Rieger and Leibfried (2004) on Confucianism.
} 
1994). Other studies focused on subsistence production as a livelihood (Arbeitsgruppe Bielefelder Entwicklungssoziologen 1979) or interpreted work in the informal sector of the economy as a "quest for security" (Evers et al. 1983). Anthropological studies of developing countries used to focus on informal relationships and livelihoods rather than new, formal welfare institutions. ${ }^{8}$ Macro theories relevant to the study of development-post-colonial theories, cultural studies, theories of economic growth, and theories of global capitalism-help to contextualise social policy but arguably are too broad to explain specific policies and institution building. ${ }^{9}$ At the same time, research on Northern welfare states had almost completely neglected countries in the Global South until the 2000s. Pioneering comparative studies include Gough et al. (2004) and Haggard and Kaufman (2008).

What theories, then, are appropriate for analysing "social policy in development contexts"? We can distinguish four strategies for theory building: drawing on "old" (extant) theories, designing new ones, adapting old theories to make them applicable to the Global South, and producing a generalised theory that applies to both North and South.

The first strategy would mean simply applying theories and conceptual instruments familiar from research on Northern welfare states to the South_-testing old theories in new surroundings" (Kangas 2012: 73). Generally, moving to a new field of investigation (here: the South) does not necessarily entail constructing new theories. The same factors could be relevant but the values could be different, such as minor industrialisation or a weak role for trade unions. By definition, developing a "theory" is ascertaining general patterns that shed light on diverse cases. Using Northern-based theories, however, might entail a Euro-centric bias that produces a negative perspective on Southern welfare, such as pointing out the "underdevelopment" of social welfare or the absence of ideas about the future among Southern citizens and, therefore, of the idea of social security (for a critique see von Benda-Beckmann and von Benda-Beckmann 1994).

\footnotetext{
${ }^{8}$ However, see the legal anthropologists von Benda-Beckmann and von Benda-Beckmann (1994)'s early study questioning the distinction between formal and informal welfare.

${ }^{9}$ Yet, see Lavinas (2017 and 2018) who relates the recent rise of social cash transfers to changes in global capitalism, especially the financialisation of social relationships.
} 
The second strategy argues for designing new concepts and theoretical tools from scratch, tailored to development contexts. Yet, it is not plausible that the broad repertoire of concepts and theories on social policy that Northern welfare state research has produced since the 1970s should be entirely irrelevant to the study of formal welfare in the South, since basic institutions, like social insurance and social assistance, are similar, at least formally.

The third strategy occupies an intermediate position between applying old theories and inventing new ones. The idea is to start from "old" concepts from Northern research and strip them of their Northern origins by adapting and re-specifying them in view of Southern conditions, as Gough (2008) explored and Böger and Leisering (2020) implemented in a case study.

The fourth strategy would also start from Northern concepts but, rather than adapting them to the South, would aim at creating a general theory of social policy that covers both North and South—a global theory of social policy. This would mean not surrendering but qualifying the ingrained distinction between the North and South. In a broader sense, Midgley (2017: 201-204) calls for a "one world perspective". A generalised (global) approach would refer to general categories of social protection that we can expect to matter in most countries (see von Benda-Beckmann and von Benda-Beckmann 1994), such as "social" contingencies (like widowhood or ill-health), related regulations (embedded in social relationships, like family life and community, or under specialised agencies, such as grain stores or hospitals), and collective agents (like family, kin, tribes, and states). Such a conceptual model does not presuppose the specific institutions, ideas, and societal contexts that have characterised the historical (Northern and Western) European experience of welfare statism. ${ }^{10}$ We can re-specify this kind of generalised model for either Southern or Northern conditions or, for that matter, to any country under investigation, whether Northern or Southern. This volume pursues the fourth strategy, which I develop in the next sections.

\footnotetext{
${ }^{10}$ For a discussion of the pioneers of a generalised North-South theory of social policy (Ian Gough, Jeremy Seekings, and Franz and Kebeet von Benda-Beckmann), see Leisering (2019: 28-32).
} 


\section{Explanatory Theories of Social Policy}

The most common approach to analysing social policy in Northern welfare state research is political economy, which Esping-Andersen (1990) exemplifies. Students of political economy centre their analysis on the capital and labour divide and conceive of social policy as a response to structural problems in formal labour markets under capitalism, politically driven by class-based actors and the grand, nineteenth-century European ideologies-liberalism, conservatism, and social democracy. The Power Resources Approach, in particular (re-stated by Korpi 2006), focuses on the struggles between employers and the labour movement and related political parties. These theorists define the purpose of social policy as "decommodification", that is, relieving workers from the pressure to sell their labour in the labour market (Esping-Andersen 1990). Social policy creates "forms of existence outside the labour market" (Offe 1984: 94) by which workers can survive if they are unemployed, sick, or old, through unemployment benefit, sick pay, and old-age pensions. Some scholars have applied a political economy approach to the comparative study of Southern countries, for example, classifying Southern welfare regimes using Esping-Andersen's typology of liberal, conservative, and social democratic welfare state regimes (e.g. Barrientos 2009).

Yet, key concepts of the classical political economy approach are of limited use in the South. Esping-Andersen's concept of decommodification presupposes wholesale commodification of labour, but labour in the South is predominantly informal, and the division between capital and labour is not as dominant as in the North. In many Southern countries, labour movements look different or play a lesser role than ethnic or religious movements (for India, see Singh 2015a, b). Moreover, the great ideologies of nineteenth-century Europe that define political party lines (liberalism, conservatism, and social democracy) are absent or take on different shapes in the South. The decommodification index (EspingAndersen 1990) and the similar generosity index (Scruggs 2007), which measure the quality of entitlements to social security benefits, make little sense if Southern politics does not address some of the key risks that the indices cover, or if programmes that cover certain risks exclude the 
majority of the population, especially the rural population, migrant workers, or persons in the informal urban labour sector. Moreover, clientelism and clan rule may eclipse formal political institutions and legal entitlements.

Tillin and Duckett (2017), in their theoretical framework for the study of social policy in Brazil, India, China, and South Africa, also qualify the power of explanatory factors common in political economy, such as political parties and ideologies, organised labour, and economic globalisation. Instead they draw attention to domestic political factors like political leaders and policy entrepreneurs, ideas, federalism, courts, and the perceived quality of government.

Nevertheless, political economy approaches in the broader sense, which emphasise the impact of economic structures on politics, have contributed to the study of Southern welfare, especially for middleincome countries (Haggard and Kaufman 2008; Huber and Stephens 2012 for Latin America; Mares and Carnes 2009; Rudra 2007). Rudra (2007) analyses varieties of decommodification in the South, while Mares and Carnes (2009) examine the impact of authoritarian governments. Haggard and Kaufman (2008) highlight "production regimes", "growth models", and "critical realignments" that denote changes in the configuration of power resources. Ulriksen (2012) draws attention to the role of taxation, and Lavinas $(2017,2018)$ emphasises the impact of the financialisation of global capitalism on domestic welfare politics. Gough's global approach builds on Esping-Andersen's concept of "welfare regime" but generalises the concept by stripping it of political economy features (Wood and Gough 2006; Abu Sharkh and Gough 2010).

Including, but going beyond political economy, Northern research has produced a comprehensive explanatory model of the emergence and expansion of the Northern welfare states-the orthodox model (Gough 2008: 5; for early integrated models see Gough 1979, Flora and Alber 1981, Alber 1982, Uusitalo 1984, and Huber et al. 1993). The orthodox model summarises and integrates the explanatory factors used in the literature, even though few authors make full use of all factors. According to the comprehensive model, three main groups of factors account for welfare state development: 
- Industrialisation, urbanisation, and other socio-economic changes (for short: Industrialisation), which create social problems but also supply the means to tackle them. The earliest studies focused on these factors, often referred to as the "logic of industrialisation" approach.

- The political mobilisation of interests (for short: Interests) like labour movements, conservative elites, and left-wing political parties, which determine if and how social problems actually elicit responses.

- The structure of political institutions (for short: Institutions), above all democracy, federalism, electoral systems, and the separation of powers, which channel the articulation of interests.

This is the "Three Is" model, which includes the components: Industrialisation, Interests, and Institutions.

In a seminal, but rarely exploited meta-theoretical article, Gough (2008) discusses the need for revising the orthodox explanatory model in view of developmental contexts in the Global South. For each of the three groups of factors - Industrialisation, Interests, and InstitutionsGough discusses the potential differences between the North and South, and he adds two more groups of factors, namely Ideas and International Influences, which we can expect to particularly matter in the South. This results in a model with five groups of factors that Gough terms the "Five Is" (Fig. 1.1).

The Five-Is model illustrates the complex multi-causality of social policy (for an application of Gough's model to social pensions see Böger and Leisering 2020). The breadth of the groups of factors and the factors within each group may seem unsatisfactory because the model does not offer a simple answer to the question of what drives welfare state development. This is a key message of the Five-Is model: grand theories that centre on one key factor like global capitalism or post-colonialism"primacy theories" (Luhmann 1997: 571; transl. L.L.)—are of little avail when attempting to explain social policy (Alber 1982: 201). Instead, a "combination of structural factors, interest-based mobilisation, political institutions, and policy discourses has determined patterns of social policy development... Social policy... [is]... embedded in structural, political, and institutional contexts" (Gough 2008: 63). The Five-Is model 


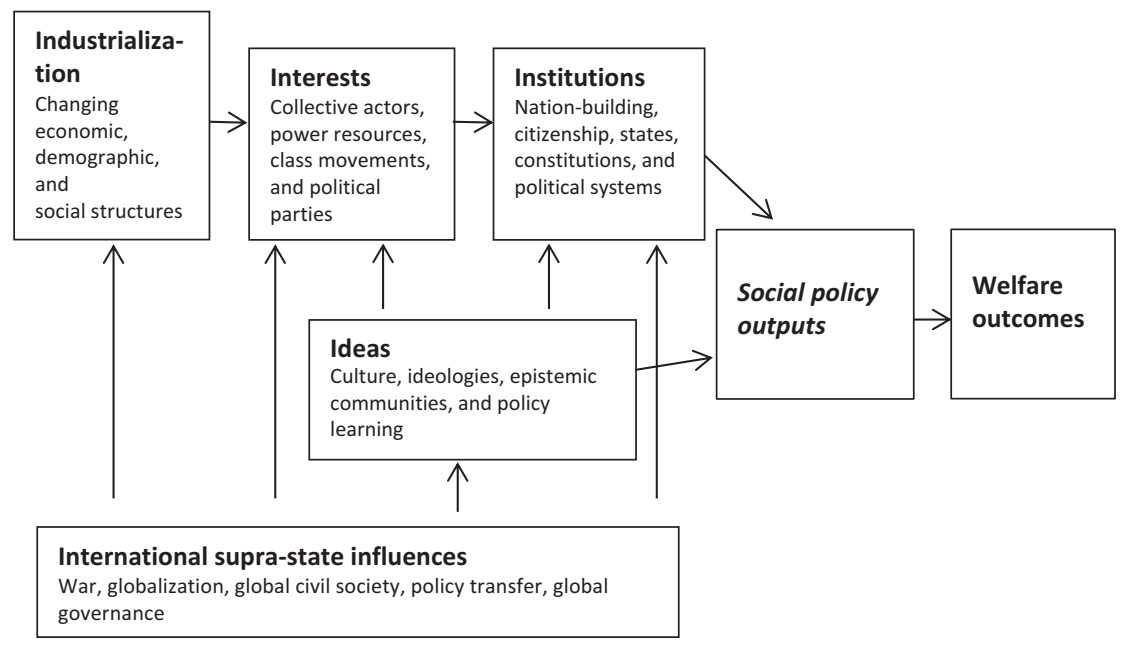

Fig. 1.1 A simple model of social policymaking (the "Five Is"). (Source: Gough 2008: 44)

implies that a range of demanding requisites must be met in order for a comprehensive social policy arrangement to emerge.

This volume focuses on the ideational requisites (Ideas), in interaction with the other four Is. I argue that ideas are no less relevant than socioeconomic power relationships (Interests) and political regimes (Institutions) and that ideas co-constitute the other "Is", following a constructivist methodology. A recent example of the way that ideas coconstitute interests is the emergence of new, individualised theories of economic development and the agency of the poor during the 1990s (von Gliszczynski 2015; von Gliszczynski and Leisering 2016). The new concepts make an economic case for social cash transfers to the poor by identifying the poor as agents of development and economic growth and conceiving of transfers to the poor as economic investment: "growth through redistribution" (von Gliszczynski 2015: 84-85). Previously, the poor had predominantly been seen as mere victims and as unable to use cash rationally.

The fifth "I", "International Influences", includes ideas. International influences were significant in the history of Northern social policy right 
from the beginning in the late nineteenth century but are particularly important in the Global South. When Southern social policy began to emerge, Northern countries had already established welfare states that Southern countries could observe and use as models. As early as the 1920s, some Chinese and Indian intellectuals identified the Northern model of social insurance as an instance of modernity that they could use to overcome the "backwardness" of their own countries, although others were critical of ILO models (Seekings 2008a). Southern policymakers considered diverse Northern programmes as models (for China see $\mathrm{Hu}$ 2015, 2016; Leisering et al. 2017) in the light of their scarcity of domestic legal and administrative expertise. Moreover, international organisations engage much more in domestic policies in Southern than Northern countries. In global discourses, social policy principles have been articulated since the "welfare internationalism" of the 1940s (Kaufmann 2012: ch. 4). In particular, the UN has championed human rights, and, since the 1990s, international organisations have increasingly turned to social issues (see Deacon et al. 1997: 3) and influenced domestic social policies worldwide.

When analysing the historical rise of social security policies in Brazil, India, China, and South Africa since the 1920s, we need to treat the Five Is as evolving social forces. The research question then is: have "social" Interests, Institutions, Ideas, and International Influences evolved at all, and, if so, when, based on what ideas, and with what impact.

\section{Conceptualising Social Policy Ideas: A Multi-layered Model ${ }^{11}$}

In order to follow Max Weber's ideational methodology depicted above, we need to trace the cognitive structure of ideas that constitute social policies. The model of the ideational structure of social policy that I present in this section differs from common conceptualisations in two respects. First, I use highly generalised concepts and categories that do not presuppose any specific social value or norm, in line with the fourth

${ }^{11}$ This section draws on Leisering (2019: 34-46). 


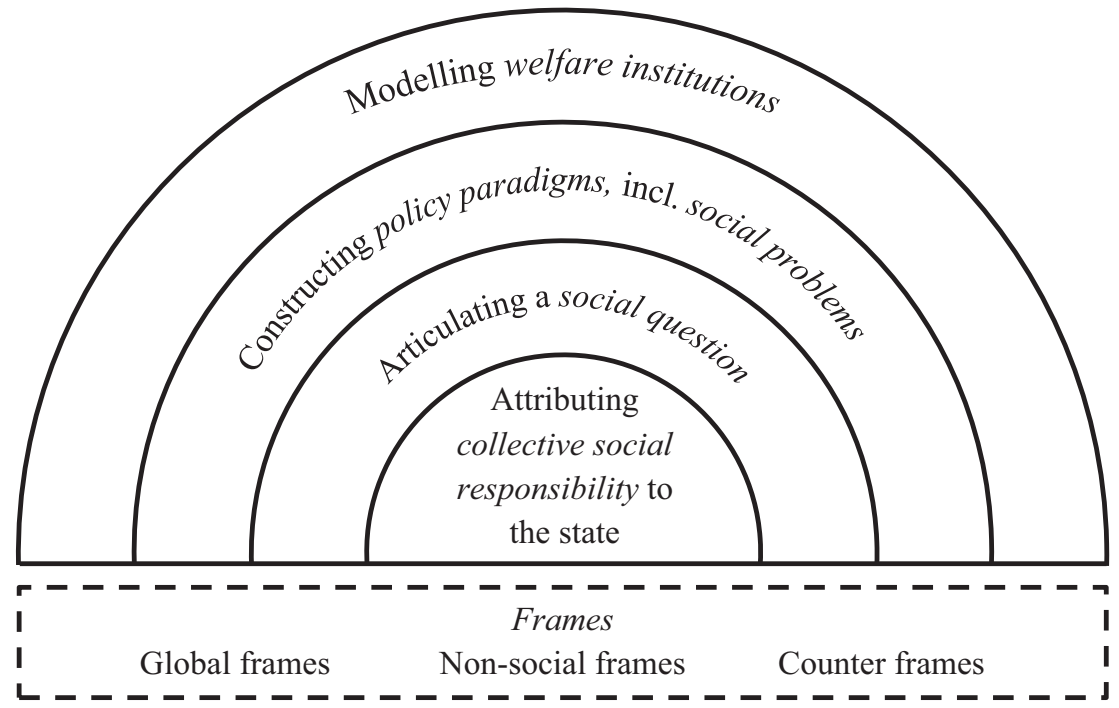

Fig. 1.2 The ideational fabric of social policy-the onion skin model. (Source: The author)

strategy for theorising social policy that I described above. Second, rather than naming single, broad ideas, like values or ideologies, I conceive of a complex multi-layered fabric of social ideas. ${ }^{12}$

I conceive of four layers, ranging from the concrete to the abstract: models of welfare institutions; policy paradigms, including social problem definitions; social questions; and collective social responsibility. Frames are a fifth, outer layer or a cross-cutting dimension. The model can be visualised as an onion with several layers (Fig. 1.2). ${ }^{13}$

The four dimensions highlight the challenges that any country faces when seeking to establish substantial social protection policies and institutions in a sustainable way: devising models for welfare institutions;

\footnotetext{
${ }^{12}$ For scattered multi-level ideational approaches to social policy, see Marshall (1981b: 96-98), Ullrich (2003), Pfau-Effinger (2005, 2009), Kaufmann (2015), Hall (1993), Nullmeier (2006: 296f.); for development contexts (and more generally), see von Benda-Beckmann and von BendaBeckmann (1994: 19-23) and Lavers and Hickey (2016); for global social policy, see von Gliszczynski (2015: 22f.).

${ }^{13}$ For an earlier version, see Leisering (2019: 34).
} 
identifying, selecting, and constructing social conditions as "social problems"; raising a broad "social question" to direct public attention to social issues; and attributing to the state and other collectivities an explicit social responsibility for the well-being of all citizens. The task of empirical analysis is to ascertain if and how each layer is realised in a country. The model leaves open which social problems the state seeks to address and what broader "social question" it articulates, which welfare institutions tackle particular social problems, and what kind of "social" responsibility the state assumes. This allows for diversity between, but also within, the North and South.

The four layers signify four connected but relatively independent dimensions of variation between different countries. Few states establish all four layers completely_these states could be called "welfare states" in a cultural sense. From a comparative perspective, two countries may differ in some layers, while resembling each other in other layers. Moreover, Southern countries may be influenced by general Northern or global ideas (bottom layers), but may set up welfare institutions (top layer) of their own making or even do without institutionalisation (decoupling). This is also true in reverse: countries may receive models for welfare institutions from other countries or international organisations but may place them in a different normative context (social question, policy paradigm) particular to that country.

This multi-layer model is anchored in the tradition of the pluralist, Weberian sociology of the welfare state depicted above. In particular, we can identify all four layers in the work of Franz-Xaver Kaufmann, even if uncombined, and we can even reconstruct the four layers from Thomas Humphrey Marshall's work. ${ }^{14}$ The layers also figure separately in the writings of some other authors. We can find the term "responsibility" in the social policy literature (e.g. in Gough et al. 2004: 30), but it is not normally developed as an analytic concept. Girvetz (1968) introduced collective social responsibility as the most abstract layer of the social, which Kaufmann (1997) then took up and explored as the hallmark of the welfare state. The concept of the social question is systematically addressed by Kaufmann (2013a: 32-33), Heclo (1995), Pankoke (1970), and

\footnotetext{
${ }^{14}$ See Leisering (2019: 37, FN 13) for Kaufmann, and Leisering (2019: 51-56) for Marshall.
} 
Castel (2003) from a historical perspective, and in global terms by Kreckel (2008), Faist (2009), Breman and van der Linden (2014), and Breman et al. (2019a). The term "policy paradigm" stems from policy analysis (Hall 1993), and the social definition of social problems, which is a part of a policy paradigm, draws on social problems theory (Schetsche 1996). The concept of frames is common in policy analysis and social analysis more generally (van Hulst and Yanow 2016).

Each of the four layers of political commitments has its own political arena, political actors, and ideational logic. The most abstract layer, the assumption of collective social responsibility, in particular, refers to states, which continue to be decisive actors in global social policy. UN human rights declarations explicitly address states as the agents in charge of implementing human rights. The concept of the state's collective social responsibility contrasts with clientelism and patrimonialism as modes of governance that do not reflect a universalistic and rights-based sense of welfare responsibility. A commitment to "the social" may be articulated in a country's constitution through "social" clauses and by ratification of the Universal Declaration of Human Rights (UN 1948), the International Covenant on Economic, Social and Cultural Rights (ICESCR; UN 1966), and other human rights documents. Constitutional assemblies, courts, legal scholars, politicians, and (sometimes) the citizenry have a hand in these processes. The assumption of collective social responsibility, if it exists, is rooted in the (national) "societal community", which Talcott Parsons (1969: 11-12, 253) sees as "the focus of solidarity or mutual loyalty".

The social question, as I defined in the first section, is the pivot of the onion skin model. The social question relates to issues of social cohesion and the integration of society. It asks "how to hold society together amid vast destabilizing change" (Heclo 1995: 675). Similarly, Castel holds that "the 'Social Question' is a fundamental aporia, through which a society experiences the enigma of its own cohesion and tries to forestall the dangers of its disintegration" (2003: xix f.). Social policy is not only about redistribution but also, at least as important but often neglected, about the social recognition of social groups and issues. In a sociological sense, the social question relates to both redistribution and recognition. By expressing social recognition, social policy addresses sociocultural aspects 
of societal integration that redistributive policies do not address (Kaufmann 2012: 21-23). The concept of the social question emerged in the 1830s and 1840s in France and Germany (Castel 2003: xx; Kaufmann 2013b: 32). "Poverty, inequality, and social injustice are ancient plagues of humankind. But they emerged as a 'social question' rather late, in a context of the Enlightenment and the Industrial Revolution-the former by putting inequality and human rights on the agenda..., and the latter by producing poverty and misery by wage labor" (Therborn 2019: ix).

The workers' question in nineteenth-century Europe referred to labour rights - the labour question. Labour rights include individual rights, the right to collective action, and the right to monetary support in case of employment-related risks, but the latter moved to centre stage only after World War II, as "social security", which extends beyond employmentrelated risks. In agrarian societies, the land question is likely to become a significant social question. The three social questions-land, labour, and social risks more generally - may interact or compete with each other. International organisations' global definitions of a social question may also influence domestic social questions. For example, around 2000, poverty became the number one social question in global social politics (Noël 2006; Hulme 2015). A comparative analysis of nationally defined social questions can distinguish welfare states on sociocultural grounds, as an alternative to classifications based on a political economy point of view. For Europe, Kaufmann (2013a, c) distinguishes between the workers' question, which has historically shaped the German welfare state, the poverty question (UK), the family question (France), and the inequality question (Sweden).

The social question may be eclipsed or even counteracted by other societal questions, especially the national question, a concern for economic growth and development, or religion. However, other questions can also support and reinforce the social question, for example, when social protection is viewed as a productive force to promote economic growth or when social policies are designed to strengthen national unity, as under Bismarck in Imperial Germany, 1883-1889, in the wake of German unification in 1871 (for China see Shi 2017).

The other societal questions often act as frames of social protection. Social policy by itself mostly enjoys only a limited legitimacy and needs 
more powerful normative underpinnings within larger constituencies. References to the collective-economic, political, and social-utility of social policy beyond individual welfare were major drivers of the rise of social policy in nineteenth- and twentieth-century Europe (Kaufmann 2012: 278-283). Frames in this sense include references to "non-social" issues, especially economic and, more recently, ecological challenges, and transnational principles that international organisations have advanced, above all human rights (which are global frames). The recognition of international organisations and donors as knowledge actors rests on their claims to represent universal, world cultural values and ideas (Meyer 2009: 186). We call frames that compete with or even counteract social policies "counter frames".

\section{A First Glimpse of the Four Countries: Basic Social, Political, and Economic Data}

Few studies compare Brazil, India, China, and South Africa in social and cultural (rather than economic) terms, but drawing on scattered literature, we can sketch a first comparative picture of the four countries.

In economic terms, all four countries have recently experienced massive growth. The "average annual increase in GDP in the BRICS countries (Brazil, Russia, India, China, and South Africa) exceeded 8 per cent in the 2000s, significantly higher than the average of 2.6 per cent in developed countries and the global average of 4.1 per cent over the same period" (ISSA 2013: 13).

While the economic rise of the four countries is widely known, it is less well known that the four countries, except for India, are currently among the leaders in social protection in the Global South (see Table 1.1, section "Social protection"). Going back in history, our four countries adopted social insurance programmes later than many Northern countries, but they were often earlier adopters (than Northern countries) if related to GDP or demographic ageing at the time of adoption (for the demographic ageing see Lindert 2004a: 218). However, as the country chapters show, the early programmes only applied to small privileged groups and implementation was weak (Midgley 1984: 117). Collier and Messick 


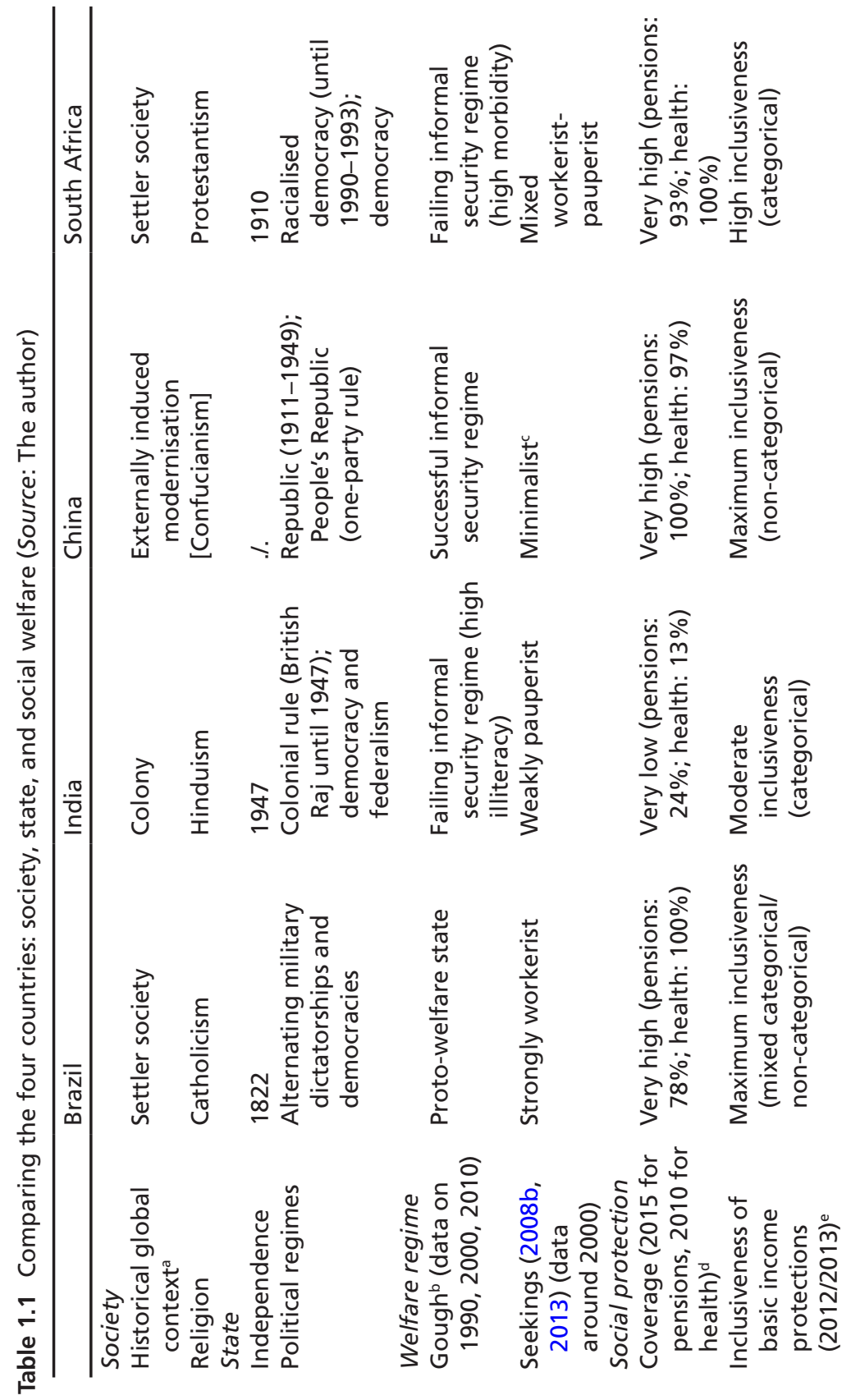




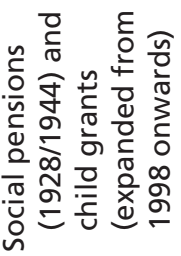

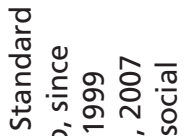

कृष्ठ

经造.

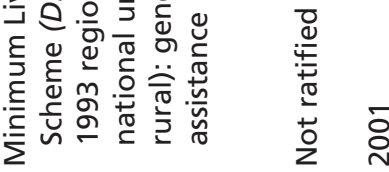

궁

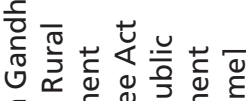

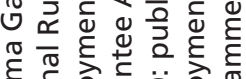

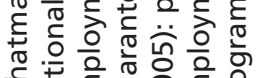

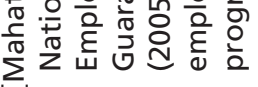

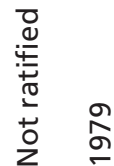

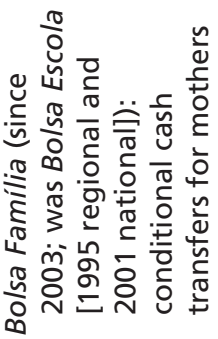

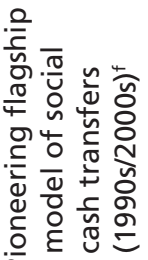

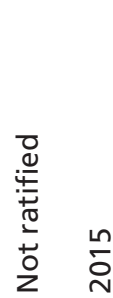

ฮั ֻั

흠 항 안

엉

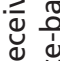

ฮ

온 ํํำ

ชั.

艺

है

$\stackrel{0}{=}$

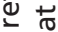

$\bar{\sigma} \frac{}{t}$

ब응

里

응

วิ

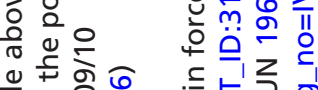

능유는

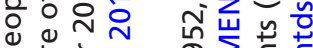

व

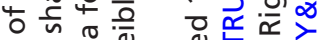

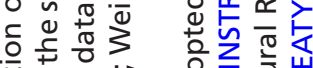

윙 잉

응 뉸

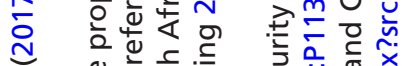

ᄃ

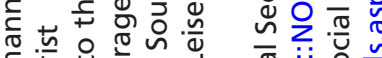

कิ

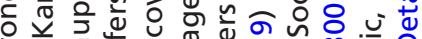

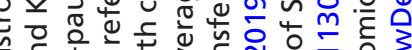

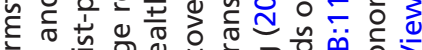

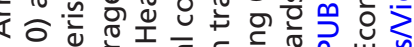

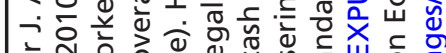

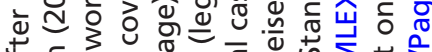

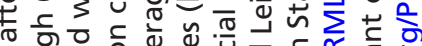

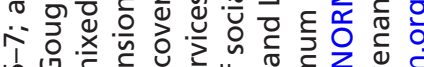
ก

й

જิ

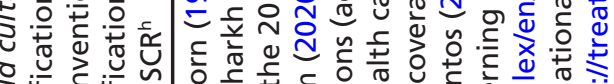

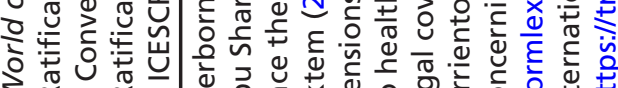
১范 
(1975) distinguish four global waves of first adoptions of social insurance up to 1960: 1883-1891, 1892-1901, 1908-1922, and 1923-1960 (no adoptions between 1901 and 1908). Roughly speaking, adoptions in Europe happened during the first, second, and third periods, making their way from Northern to Southern Europe; adoptions in Latin America and former British colonies occurred in the third (including Brazil and South Africa) and fourth periods; and adoptions in the Middle East and Asia occurred in the fourth period (including China, but excluding Japan, whose adoption took place in the third).

The picture of the overall welfare regime in the four countries (Table 1.1, section "Welfare regime") is more variegated and less impressive than the data on social protection in the Table, which only refers to basic income protection and coverage and disregards benefit levels, welfare outcomes, and dimensions like morbidity and literacy. Gough et al. (2004), Abu Sharkh and Gough (2010), and Wood and Gough (2006) generalise Esping-Andersen's concept of "welfare regime" to simply "regime" and distinguish between three global types of regimes: "welfare state regimes" as Esping-Andersen originally conceived of Northern welfare states, "informal security regimes", and "insecurity regimes". The assumption is that security is a meaningful category not only for welfare states ("social security") but also in development contexts (similarly von BendaBeckmann and von Benda-Beckmann 1994), and that informal (nonstate) agencies have a bigger share in generating security in developing countries. The studies by Gough, which include Eastern European countries, name around fifteen "proto-welfare state regimes", including Brazil, that are countries bordering on becoming Northern welfare state-like regimes. From 1990 to 2010, the proto-welfare state regimes have been relatively stable (for 2010 see Karmann's 2017 re-analysis and update of Abu Sharkh and Gough's study).

Seekings (2008b, 2012, 2013) applies the nineteenth-century European distinction of policy for workers versus policy for the poor to the Global South, distinguishing between workerist welfare regimes (that rely on employment-based social insurance for formal workers) and pauperist welfare regimes (that rely on poor relief or, later on, on meanstested social assistance programmes, including social pensions) in the early and mid-twentieth century. In addition, Seekings describes 
land-based agrarian regimes, and "minimalist" regimes that lack a clear orientation towards either workers or the poor and spend less than average on both. By the end of the twentieth century, Seekings posits a decline in agrarian regimes and a recasting and expansion of pauperist regimes as citizen-based social security regimes, founded on social cash transfers. According to Seekings, our four countries fall into distinct types (see Table 1.1, section "Welfare regime", second line).

The political regimes (see Table 1.1, section "State") differ between the four countries, and all four underwent marked changes during the twentieth century. Regarding national independence, only China was formally never dependent, except limited territories.

The four countries differ considerably concerning their historical links to the world society (Table 1.1, section "Society"). India was a colony, while South Africa and Brazil were not simply colonised, but also settled, through waves of immigration by farmers, workers, and slaves. The four countries also represent distinct world religions, which give us a first clue to the country's chances for public social welfare. Roman Catholicism has an affinity for state welfare (as has Islam; Lindert 2004a: 219), whereas Protestantism comes in pro- and anti-welfare state varieties (van Kersbergen and Manow 2009). Confucianism, a Weltanschauung rather than a religion, is seen by some as adverse to extended public welfare (Rieger and Leibfried 2004).

All four countries had weak formal links to global "social” norms (world society links) after World War II and forged them rather late (Table 1.1, section "World cultural links").

All four countries experienced considerable economic growth over the last hundred years (Fig. 1.3), but India and China stagnated for a very long period of time, 1920 to c. 1980. South Africa was in the lead until 1980 , but was surpassed by Brazil thereafter. China skyrocketed in the 2000s, while India like China started to grow in the 1980s, but at a much lower pace. All four countries experienced a massive upturn in the $1990 \mathrm{~s}$ and 2000s, but growth rates abated in the 2010 s.

Over the last three decades, social progress has been massive in all four countries (Table 1.2), but they started from exceedingly low levels regarding life expectancy at birth, literacy, and poverty. India scores lowest, followed by South Africa. By and large, advancement has been 


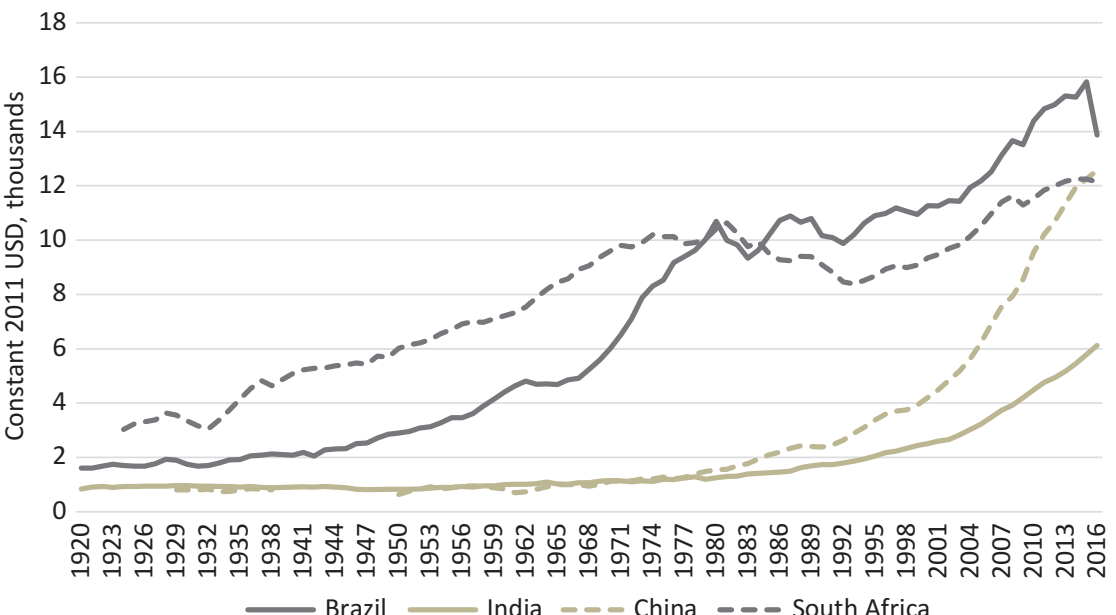

Fig. 1.3 Real GDP per capita in 2011 USD in Brazil, India, China, and South Africa. (Source: The author, data from Maddison Project Database, version 2018; Bolt et al. 2018)

continuous, but the curve of life expectancy in South Africa reflects the HIV-created bulge in the 1990s and 2000s. China has caught up and nowadays surpasses the other three countries, while Brazil has fallen behind in relative terms. The figures only give a rough picture, since they were reported by the countries themselves.

Despite economic growth and social betterment, all four countries are riddled with excessive inequality of incomes, with South Africa as the most extreme case (Fig. 1.4). Inequality has increased massively since 1980 - the cost of economic growth. All four countries are "large uneven developers" (Frazier 2011: 90). Moreover, the social organisation of labour, especially the vast informal labour and the low participation of women in the labour force, above all in India (Table 1.3), differs sharply from most countries of the Global North. Inequality, informal labour, and the position of women are major challenges and limitations to social policy. The high share of rural workers also raises issues of social protection. Industrial employment has risen in India and China, but deindustrialisation and the rise of the service economy already show in the recent figures, except for India. 
Table 1.2 Basic social indicators for Brazil, India, China, and South Africa

\begin{tabular}{|c|c|c|c|c|c|c|}
\hline \multicolumn{7}{|c|}{$\begin{array}{l}\text { Extreme poverty (1.90 USD a day, } 2011 \text { purchasing power parity; in percentage } \\
\text { of population) }\end{array}$} \\
\hline & 1993 & 1996 & 2005 & 2011 & 2014 & 2016 \\
\hline Brazil & 19.9 & 14.2 & 8.6 & 4.7 & 2.7 & 3.9 \\
\hline India & 45.9 & - & $38.2^{\mathrm{a}}$ & 21.2 & - & - \\
\hline China & 56.6 & 41.7 & 18.5 & 7.9 & 1.4 & 0.5 \\
\hline South Africa & 31.7 & 36.6 & 26.1 & $16.5^{b}$ & 18.9 & - \\
\hline \multicolumn{7}{|c|}{ Literacy (in per cent of people aged $15+$ ) } \\
\hline & 1980 & 1990 & 2000 & 2006 & 2011 & 2018 \\
\hline Brazil & 74.6 & - & 86.4 & 89.6 & 91.4 & 93.2 \\
\hline India & $40.8^{c}$ & $48.2^{\mathrm{d}}$ & $61.0^{\mathrm{e}}$ & 62.8 & 69.3 & 74.4 \\
\hline Chin & $65.5^{f}$ & 77.8 & 90.9 & - & $95.1^{9}$ & 96.8 \\
\hline South Africa & 76.2 & - & - & $88.7^{\mathrm{h}}$ & 93.1 & $87.0^{\mathrm{i}}$ \\
\hline \multicolumn{7}{|c|}{ Life expectancy at birth } \\
\hline & 1965 & 1975 & 1985 & 1995 & 2005 & 2017 \\
\hline Brazil & 56.6 & 60.9 & 64.4 & 68.3 & 71.9 & 75.5 \\
\hline India & 44.5 & 51.0 & 55.8 & 60.3 & 64.5 & 69.2 \\
\hline China & 49.5 & 63.9 & 68.5 & 69.9 & 73.0 & 76.5 \\
\hline South Africa & 50.3 & 55.4 & 60.9 & 61.6 & 53.4 & 63.5 \\
\hline
\end{tabular}

Source: The author, data from World Bank (n.d.), World Development Indicators a2004

b2010

‘1981

d1991

e 2001

${ }^{f} 1982$

92010

h 2007

i2017

In response to the social problems arising from industrialisation, urbanisation, dislocation, and other social processes, all four countries took social policy measures. Social spending is a rough measure of social effort. Differences in social spending between the four countries (Fig. 1.5) roughly correspond to the differences in real per capita GDP between the countries (as shown in Fig. 1.3), with two exceptions. Brazil is a big social spender, much more ahead of South Africa than its real per capita GDP would suggest. This might be partially explained by the share of social insurance in Brazil. The second exception is China, which ranks relatively low in social spending as compared to its high ranking in real per capita GDP. Since China has considerably expanded the coverage of social 


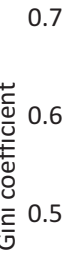

0.4

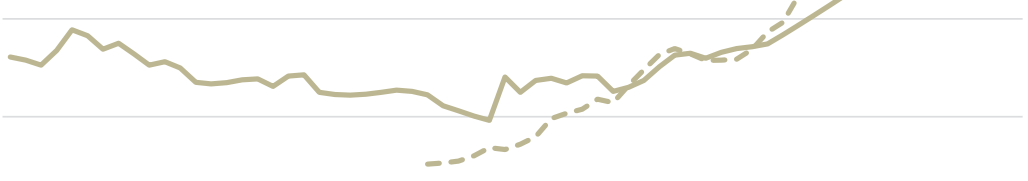

0.3

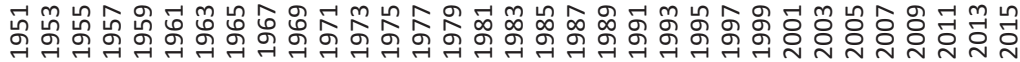
Brazil - India - - China - - - South Africa

Fig. 1.4 Gini index of income in Brazil, India, China, and South Africa. (Source: The author, data from Alvaredo et al. n.d., World Inequality Database)

Table 1.3 Basic labour indicators for Brazil, India, China, and South Africa

\begin{tabular}{|c|c|c|c|c|}
\hline \multicolumn{5}{|c|}{ Employment in industry (in percentage of total employment) } \\
\hline & 1991 & 2000 & 2010 & 2019 \\
\hline Brazil & 23.3 & 21.9 & 22.5 & 19.8 \\
\hline India & 15.7 & 16.3 & 21.8 & 25.6 \\
\hline China & 21.4 & 22.5 & 28.7 & 28.2 \\
\hline South Africa & 28.7 & 27.3 & 24.4 & 22.9 \\
\hline \multicolumn{5}{|c|}{ Informal employment (in per cent of total non-agricultural employment) } \\
\hline & 2000 & 2009 & 2013 & 2018 \\
\hline Brazil & - & 42.0 & 37.0 & - \\
\hline India & - & $75.3^{\mathrm{a}}$ & $74.8^{\mathrm{b}}$ & 80.3 \\
\hline China & - & - & - & - \\
\hline South Africa & 53.8 & 33.4 & 32.4 & 35.2 \\
\hline \multicolumn{5}{|c|}{$\begin{array}{l}\text { Female labour force participation (in percentage of the female population } \\
\text { aged 15-64) }\end{array}$} \\
\hline & 1990 & 2000 & 2010 & 2019 \\
\hline Brazil & 44.8 & 53.9 & 58.6 & 60.7 \\
\hline India & 31.8 & 31.9 & 27.1 & 24.7 \\
\hline China & 79.4 & 76.8 & 69.6 & 68.7 \\
\hline South Africa & 45.4 & 52.4 & 48.3 & 53.5 \\
\hline
\end{tabular}

Source: The author, data from ILO (n.d.), ILOSTAT database, estimates a2010

${ }^{\mathrm{b}} 2012$ 


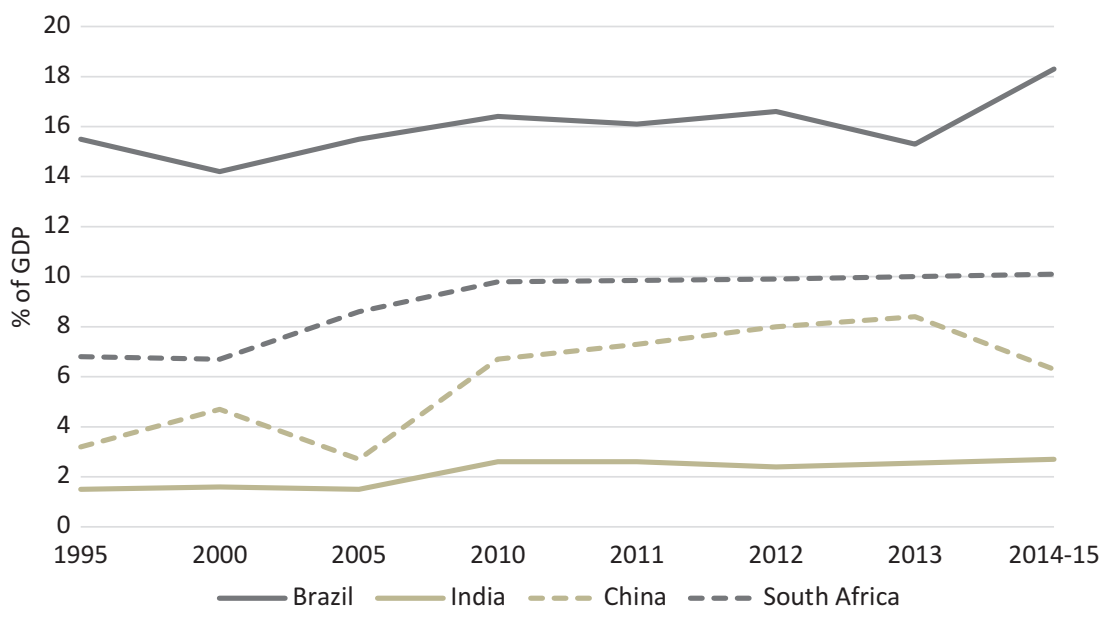

Fig. 1.5 Public social protection expenditure (in \% of GDP) in Brazil, India, China, and South Africa. (Source: The author, data from ILO 2017: 397-404, Table B.16; for definitions and data sources see ILO 2017: 199-209, Annex II)

protection during the 2000s and early 2010s, low spending might indicate low benefit levels and patchy implementation. India ranks lowest, as on most other accounts. This suggests that there is little political effort to address the widespread poverty and destitution in the country. However, the overall trend in social spending is upwards in all four countries. In China, the increase is not linear, seemingly reflecting the swings in social protection policies analysed in Chap. 3 of this volume.

Social problems abounded in all four countries, and over the last hundred years, the Brazilian and the South African economies increasingly provided resources to tackle them. In India and China, real economic growth started as late as the 1980s. Economic performance relates to the factor bundle "Industrialisation" in Gough's explanatory model of welfare state development, the Five Is model, as outlined above. In 1920, all countries started from a roughly similar low economic level, except South Africa which had a per capita GDP that was double India's and China's per capita GDP (Fig. 1.3). The question is if, when, and how the countries addressed their social problems. Regarding politics and polity (factor bundles "Interests" and "Institutions" in Gough's Five Is model), all 
countries were to experience considerable upheaval, including war, civil war, foreign oppression, struggle for independence, revolution, and authoritarian rule, all of which may eclipse-or fuel_- "social" concerns. The chapters in this volume bring in the factor bundle "Ideas" (and International Influences) from Gough's Five Is model, conceptualised as a complex configuration, the onion skin model.

\section{The Chapters}

The volume has two chapters on each country, except South Africa, for which there are three chapters.

China is the only socialist country among the four countries, at least since 1949. The two chapters on China by $\mathrm{Hu}$ Aiqun and Shi Shih-Jiunn (Chaps. 2 and 3) focus on the years 1912-1949 and 1978-2020, the People's Republic of China's reform era. Both chapters address the years 1949-1978, but in less detail, because they have been much researched earlier.

Hu Aiqun argues that the thirty years before 1949 were formative years that provided the foundations for social legislation after 1949 when the People's Republic of China was founded and the Nationalist government retreated to Taiwan. The decades before 1949 witnessed the public emergence of "social" issues in intellectual debates, bills, acts, and public language, including the concept of "social security". The quest for stability by a society torn apart by economic backwardness, foreign oppression, and social divisions provided the context for the rise of the social question. Chinese elites turned to a range of Western social ideas to "save the nation" in the face of imperialism. Some actors adopted communism, whereas reformist intellectuals espoused organic concepts of society that led to a concern for stability and harmony. In the 1930s, the Nationalist Party in government reinterpreted Confucianism as part of its state ideology to answer the need for stability. During the Sino-Japanese war, Chinese elites were attracted to the contemporary global idea of universal social security, and this fuelled developments in social security. Although Western ideas played an important role, Chinese elites emphasised China's "special situation". 
Shi Shib-Jiunn analyses the changing semantics of social policy in China as an indicator of changing policies. He argues that social policy in China was not just socialist in an egalitarian sense but has been subject to considerable swings regarding institutional design, concepts, terms, and frames, and that the swings ensued from the Communist Party's legitimacy problems. These systemic concerns rather than those for individual rights shaped social policy. Accordingly, Shi reconstructs four recent phases of development in China: under socialism (1949-1978) the social question was seen to be resolved in the institutions of socialist production, and social protection programmes centred on urban workers. The reform years after 1978 witnessed the advent of the social question, first through the "socialisation" of social welfare (transferring social responsibility from the state to non-state agencies) and "GDPism" from 1978 to 2000. From 2000 to 2012, the state massively expanded social protection under the flag of "social security", "inclusive growth", and "social management". Since the authoritarian turn in 2012, social protection is understood as "social governance", including using surveillance systems rather than supporting individual rights and civil society activity, in order to achieve national greatness ("Chinese Dream").

The first chapter on India by Sony Pellissery (Chap. 4) takes a broad view, covering the last hundred years of social policies against the background of India's history and culture. The second chapter on India by Ravi Ahuja (Chap. 5) focuses more specifically on issues of labour protections in late colonial India.

Sony Pellissery's main argument is that in India the social question has been stifled until the present day. The idea of the state's universalistic concern for the individual welfare of all members of society never materialised. Rather, narrow and particularistic versions of the social question prevailed, which related to scheduled castes and tribes, poverty, and hunger. Caste-based social identity rather than citizenship informed calls for extending social protections. Pellissery names several reasons for this. After independence in 1947, other concerns, especially nation-building and economic development, crowded out the social question. Several visions of society competed with each other (those of Gandhi, Nehru, and Ambedkar), but only Ambedkar's vision reflected a (weak) notion of the social question. The broader background includes traditional 
Hinduism, which culturally denies equality and is tangible in the caste system. There has been a strong move towards political and legal equality, but this has been of little avail in the face of vast socio-economic inequality. From the late-twentieth century, social issues have become stronger but mostly in a particularistic and populist vein.

Ravi Ahuja aligns with Pellissery's finding of a weak social question in India. Up to the present day, India has never come even near to institutionalising social protection as a part of citizenship. Through an in-depth analysis of a limited time period, Ahuja draws a variegated picture of social ideas and legislation. Legislation was passed as early as the 1910s, passage continued during the interwar years, and reached a peak from 1946 to 1952, with the Employees' Social Insurance Act of 1948 as its core. The intimations of a social question were limited: it only concerned labour (the labour question) and only formal workers, resulting in "minoritarian labour welfare". Social legislation was generally patchy, applied only to select industries and types of workers, and included many exceptions. Moreover, there was a massive decoupling between legislation and implementation. At the same time, Ahuja also demonstrates that there were repeated calls to extend the coverage of social rights and to turn social rights into a "birthright". However, this "horizon of expectation" never materialised. External ideas from the ILO and the UK made themselves felt but mostly only influenced political language. Ahuja, a labour historian, also argues that the distinction between formal and informal labour was not a given economic distinction but was co-created by social law.

The chapters on South Africa and Brazil relate to settler societies. The three chapters on South Africa investigate pre-apartheid South Africa (1910-1948), apartheid South Africa (1948-1990), and the postapartheid years.

In the chapter on pre-apartheid South Africa (Chap. 6), Jeremy Seekings finds a remarkable expansion in the state's social protection that started in the 1920s. By 1948, a "nascent welfare state" had emerged, a kind of liberal welfare regime. The contours of the social question became visible with the rise in the usage of comprehensive terms like "social policy" (1934) and "social security" (1942). The social question was racialised throughout this period: the "poor white problem" was the state's key 
concern. To secure the whites' morals and behaviours, the social question included concern for deviant behaviours to be addressed through social work and institutional care. Moreover, there was a decoupling between legislation and implementation. Seekings argues that beyond the general racist fabric of South African politics, we need to trace specific ideas and cultural factors to explain the development of social protection policies. South African politics and society developed a range of ideas to justify their models of society and resultant social policies. These ideas were in flux, and pro as well as antisocial policy views were advanced. Afrikaner nationalists were ambivalent about social policy, whereas neo-Calvinists opposed state-provided social protections. Key ideas of the time included the whites' superior "civilisation", which gave rise to a racial hierarchy, and the "native question" that eclipsed (and shaped) the social question, Reformed Protestantism, especially neo-Calvinism, and the quest for modernising society.

Marianne Ulriksen's chapter on apartheid South Africa (Chap. 7) shares Seekings' assumption that ideas matter under a racist regime. The "poor white problem" of the pre-apartheid period became part of the wider "civilised workers' question", by which the government sought to secure racial purity, framed by the idea of "separate development" for different races. The civilised workers' question reflected the uneasy intersection of race and class in South Africa that gave the labour question a unique nature. There was little change in the design of welfare programmes (oldage pensions) throughout this period. However, the conceptions of racial relationships and collective social responsibility changed. The state's social responsibility was racially graded since the beginning, but in this era, the state further divided it through the creation of separate "homelands" for the non-white population, under the new frame "independent nations". Only towards the end of the period did more universalistic notions of social responsibility emerge under pressure from anti-regime activists and global protests. Ulriksen draws on contemporary documents, as the other contributors do, but she also makes use of qualitative content analysis.

Jeremy Seekings' second chapter, on post-apartheid South Africa (Chap. $8)$, investigates the changes in the social question after 1994. He focuses on the key reformer of the 2000s, Zola Skweyiya, who was Minister of 
Social Development from 1999 to 2009 . Remarkably, the state did not extend social protections during the 1990 s, the advent of democracy notwithstanding. Yet, the 2000s witnessed a substantial expansion under Skweyiya. Seekings argues that the social question was significantly reformulated as an issue of dignity. This reframing went beyond economic developmentalism and labourism, both of which narrowed the social question to the concerns of formal workers. Besides dignity, the social question was also phrased in terms of rights, with the courts assuming an important role in implementing and discussing the social question. Skweyiya embodied a paternalistic conservatism that linked developmentalism with broader social concerns for the poor and the dignity of all citizens. Still, the social question remained limited, providing only partial legitimisation for a welfare state. Although social protections were imagined as universal, practically, they were mainly for formal workers, and social cash transfers were only for groups seen as deserving. Attitudes in South African politics about social issues remained ambivalent, especially those of the members of the ruling party, the African National Congress (ANC), which remained labourist. The ANC's developmentalism also checked the extension of social protections. The social question was also eclipsed by a concern for political and civil rights rather than social rights. Seekings also demonstrates that social protection ideas and policies cut across the regime change of 1994 . Yet, the legacy of apartheid also fuelled calls for dignity and universal rights that were conducive to expanding social protection.

Lena Lavinas' chapter (Chap. 9) depicts Brazil's rich history of ideas, political actions, legislation, and changes in political regime but also the structural limitations of social protections until the present day. Contributory social insurance began in the 1920s, laying the foundation for later expansion and shaping social protection since. Lavinas identifies five social questions over the past hundred years: people's needs were at the origins of the first massive mobilisation at the turn of the twentieth century; the labour question was at the centre of political struggles from the 1920s, but the land question also lingered from the 1950s onward. The more general social question-social protection for all citizens including the poor-only became significant after 1988, under democracy, when a comprehensive social security system was introduced, with contributory pensions, labour-related benefits, anti-poverty targeted 
benefits, and universal health coverage. More recently, the social question has been reframed by claims of inclusiveness. The Citizen Constitution of 1988 played a major role in advancing social legislation. However, the discrepancy between talk and action, legislation and implementation (decoupling), was massive. Brazil underwent several extreme political regime changes; yet social policies have increased under both democracy and dictatorship. Under the first period of dictatorship (Vargas, 1930-1945), social policy was instrumentalised as a means of social control through state-organised labour relations while denying civil rights. During the second period of dictatorship (1964-1985), social protection was modernised. After 1988, social security remained largely underfinanced. The overall arrangement of social protection remains fragmented and selective. The deep social and racial cleavages in Brazilian society remain a major challenge.

Gabriel Ondetti's chapter (Chap. 10) on Brazil is the only chapter in the volume that focuses on the land question or, as it is mostly referred to in Brazil, the "agrarian question". Brazil has one of the most unequal distributions of land in the world, which has been a major factor in politics and society. Ondetti shows that the three big social questions-in historical order: the land question, the labour or workers question, and the broader social question comprising social protection-may exist in parallel, may compete, or may relieve each other. For example, the introduction of rural pensions in 1971 and conditional social cash transfers in the 2000s diverted attention from the land question. Ondetti depicts the broad range of ideas that shaped the social question including doctrines like reformism, communism, labourism, left Catholicism, legal doctrines, and, more recently, environmentalism. Economic interests and ideas could be pro or contra land reform. Legal ideas were the earliest: the lawyer Duguit conceived of a "social function of property" in 1911, which was taken up in political debates later, as were Torres' ideas of 1914 on land reforms. External ideas also mattered: Duguit was French; socially focused European constitutions influenced the constitutions of 1934 and 1946; and the Second Vatican Council (1962-1965) shaped left Catholicism. Ondetti depicts the range of instruments used or designed for land policies and concludes that a far-reaching response to the land question-a thorough redistribution of land-never materialised, not even under recent leftist governments. 


\section{References}

Achinger, Hans (1979) Sozialpolitik als Gesellschaftspolitik. Von der Arbeiterfrage zum Wohlfahrtsstaat, 3rd ed. Frankfurt am Main: Eigenverlag des Deutschen Vereins für öffentliche und private Fürsorge (first published 1958).

Abu Sharkh, Miriam and Ian Gough (2010) Global welfare regimes: a cluster analysis. Global Social Policy 10,1: 27-58.

Alber, Jens (1982) Vom Armenhaus zum Wohlfahrtsstaat. Analysen zur Entwicklung der Sozialversicherung in Westeuropa. Frankfurt a. M.: Campus.

Alvaredo, Facundo, Lucas Chancel, Thomas Piketty, Emmanuel Saez, and Gabriel Zucman (n.d.) World Inequality Database. https://wid.world/, accessed 27 April 2020.

Amenta, Edwin and Alexander Hicks (2010) Research methods. In: The Oxford Handbook of the Welfare State, eds. Francis G. Castles, Stephan Leibfried, Jane Lewis, Herbert Obinger, and Christopher Pierson, Oxford et al.: Oxford Univ. Press, 105-120.

Arbeitsgruppe Bielefelder Entwicklungssoziologen (1979) Subsistenzproduktion und Akkumulation, eds. Hans-Dieter Evers et al., Saarbrücken: Breitenbach.

Baldwin, Peter (1990) The politics of social solidarity. Class bases of the European welfare state 1875-1975. Cambridge: Cambridge University Press.

Barrientos, Armando (2013) Social assistance in developing countries. Cambridge et al.: Cambridge University Press.

Barrientos, Armando (2009) Labour markets and the (hyphenated) welfare regime in Latin America. Economy and Society 38,1: 87-108.

Béland, Daniel (2009) Ideas, institutions, and policy change. Journal of European Public Policy 16,5: 701-18.

Béland, Daniel and Klaus Petersen (2014) Analysing social policy concepts and language. Comparative and transnational perspectives. Bristol: Policy Press.

Bolt, Jutta, Robert Inklaar, Herman de Jong, and Jan Luiten van Zanden (2018) Rebasing 'Maddison': new income comparisons and the shape of long-run economic development. Maddison Project, Working Paper 10. https://www.rug. nl/ggdc/html_publications/memorandum/gd174.pdf, accessed 23 April 2020.

Blyth, Mark (2002) Great transformations. Economic ideas and institutional change in the twentieth century. New York: CUP.

Breman, Jan and Marcel van der Linden (2014) Informalizing the economy: the return of the social question at a global level. Development and Change 45,5: 920-40. 
Breman, Jan, Kevan Harris, Ching Kwan Lee, and Marcel van der Linden (eds.) (2019a) The social question in the twenty-first century: a global view. University of California Press.

Breman, Jan, Kevan Harris, Ching Kwan Lee, and Marcel van der Linden (2019b) Postscript: the social question in its global incarnation. In The social question in the twenty-first century: a global view, eds. Jan Breman, Kevan Harris, Ching Kwan Lee, and Marcel van der Linden, University of California Press, 244-250.

Böger, Tobias and Lutz Leisering (2020) A new pathway to universalism? Explaining the spread of "social" pensions in the Global South, 1967-2011. Journal of International Relations and Development 23: 308-338.

Castel, Robert (2003) From manual workers to wage laborers. Transformation of the social question. Transaction Publishers (republished by Routledge 2017; French 1995).

Campbell, John L. (2002) Ideas, politics, and public policy. Annual Review of Sociology 28: 21-38.

Collier, David and Richard E. Messick (1975) Prerequisites versus diffusion: testing alternative explanations of social security adoption. The American Political Science Review 69,4: 1299-315.

Deacon, Bob, with Michelle Hulse and Paul Stubbs (1997) Global social policy. International organizations and the future of welfare. London et al.: SAGE.

de Swaan, Abram (1988) In care of the state. Health care, education and welfare in Europe and the USA in the modern era. Oxford, New York: Oxford University Press.

Esping-Andersen, Gøsta (1990) The three worlds of welfare capitalism. Cambridge: Polity Press.

Evers, Hans-Dieter, Georg Elwert, and Werner Wilkens (1983) Die Suche nach Sicherheit: Kombinierte Produktionsformen im sogenannten Informellen Sektor. Zeitschrift für Soziologie 12,4: 281-96.

Faist, Thomas (2009) The transnational social question: social rights and citizenship in a global context. International Sociology 24: 7-35.

Fakier, Khayaat and Ellen Ehmke (eds.) (2014) Socio-economic insecurity in emerging economies: building new spaces. London et al.: Routledge.

Fischer, Frank (2003) Reframing public policy. Discursive politics and deliberative practices. Oxford: Oxford University Press.

Flora, Peter and Jens Alber (1981) Modernization, democratization and the development of welfare states in Western Europe. In The development of welfare states in Europe and America, ed. Peter Flora and Arnold J. Heidenheimer, New Brunswick, NJ: Transaction Books, 37-80. 
Flora, Peter, and Arnold J. Heidenheimer (eds.) (1981) The development of welfare states in Europe and America. New Brunswick: Transaction Books.

Frazier, Mark W. (2011) Welfare policy pathways among large uneven developers. In Beyond the Middle Kingdom. Comparative perspectives on China's capitalist transformation, ed. Scott Kennedy. Stanford: Stanford University Press, 89-109.

Rodgers, Gerry (ed.) (2013) Aligning economic and social goals in emerging economies. Employment and social protection in Brazil, China, India and South Africa. New Delhi: Academic Foundation.

OECD (2010) Tackling inequalities in Brazil, China, India and South Africa. The role of labour market and social policies. OECD Publishing.

Girvetz, Harry (1968) Welfare state. In International Encyclopedia of the Social Sciences, ed. David L. Sills, Chicago, IL: Macmillan, 512-21.

Gough, Ian (1979) The political economy of the welfare state. London: Macmillan. Gough, Ian, Geof Wood, Armando Barrientos, Philippa Bevan, Peter Davis, and Graham Room (2004) Insecurity and welfare regimes in Asia, Africa and Latin America. Cambridge: Cambridge University Press.

Gough, Ian and Göran Therborn (2010) The global future of welfare states. In The Oxford Handbook of the Welfare State, eds. Francis G. Castles, Stephan Leibfried, Jane Lewis, Herbert Obinger, and Christopher Pierson, Oxford: Oxford University Press, 703-20.

Gough, Ian (2008) European welfare states: Explanations and lessons for developing countries In Inclusive states: social policy and structural inequalities, eds. Anis A. Dani and Arjan de Haan, Washington DC: World Bank, 39-72.

Haggard, Stephan and Robert R. Kaufman (2008) Development, democracy, and welfare states. Princeton, NJ: Princeton University Press.

Hall, Peter (1993) Policy paradigms, social learning, and the state: the case of economic policymaking in Britain. Comparative Politics 25,3: 275-96.

Heclo, Hugh (1974) Modern social politics in Britain and Sweden. New Haven: Yale University Press.

Heclo, Hugh (1995) The social question. In Poverty, inequality, and the future of social policy. Western states in the new world order, eds. Katherine MacFate, Roger Lawson, and William Julius Wilson, New York: Russell Sage Foundation, 665-92.

Holzmann, Robert, Lynne Sherburne-Benz, and Emil Tesliuc (2003) Social risk management: the World Bank's approach to social protection in a globalizing world. Washington DC: World Bank.

Hort, Sven E. O. and Stein Kuhnle (2000) The coming of East and South-East Asian welfare states. Journal of European Social Policy 10,2: 162-84. 
Hu, Aiqun (2015) China's social insurance in the twentieth century: a global historical perspective. Leiden: Brill Academic Publisher.

$\mathrm{Hu}$, Aiqun (2016) Social insurance ideas in the People's Republic of China: a transnational and historical analysis. Transnational Social Review 6,3:297-312.

$\mathrm{Hu}$, Aiqun and Patrick Manning (2010) The global social insurance movement since the 1880s. Journal of Global History 5,1: 125-48.

Huber, Evelyne, Charles Ragin, and John D. Stephens (1993) Social democracy, Christian Democracy, constitutional structure, and the welfare state. American Journal of Sociology 99,3: 711-49.

Huber, Evelyne and John D. Stephens (2012) Democracy and the left. Chicago, IL: University of Chicago Press.

Hulme, David (2015) Global poverty. Global governance and poor people in the post-2015 Era, 2nd ed. New York: Routledge.

ILO (2017) World Social Protection Report 2017-19. Universal social protection to achieve the Sustainable Development Goals. Geneva: ILO.

ILO (n.d.) ILOSTAT Database. https://ilostat.ilo.org/data/, accessed 27 April 2020.

ISSA (2013) Social security coverage extension in the BRICS: a comparative study on the extension of coverage in Brazil, the Russian Federation, India, China and South Africa. Geneva: International Social Security Association.

Janowitz, Morris (1976) Social control of the welfare state. New York: Elsevier.

Karmann, Anna (2017) Kontinuität in krisenhaften Zeiten?-Eine clusteranalytische Überprüfung des Wohlfahrtsregimekonzepts nach Miriam Abu Sharkh und Ian Gough. Bachelor Thesis, Bielefeld University.

Kangas, Olli E. (2012) Testing old theories in new surroundings: the timing of first social security laws in Africa. International Social Security Review 65,1: 73-97.

Kaufmann, Franz-Xaver (1991) Wohlfahrtskultur - ein neues Nasobem? In: Kritik und Engagement. Soziologie als Anwendungswissenschaft, eds. Reinhardt P. Nippert, Willi Pöhler und Wolfgang Slesina, Munich: Oldenbourg, 19-27.

Kaufmann, Franz-Xaver (1997) Herausforderungen des Sozialstaates. Frankfurt am Main: Suhrkamp.

Kaufmann, Franz-Xaver (2012) European foundations of the welfare state. New York et al.: Berghahn Publishers.

Kaufmann, Franz-Xaver (2013a) Variations of the welfare state. Great Britain, Sweden, France and Germany between capitalism and socialism. German Social Policy 5, ed. Lutz Leisering. Berlin: Springer (first published in German 2001/2003). 
Kaufmann, Franz-Xaver (2013b) Thinking about social policy. The German Tradition. German Social Policy 1, ed. Lutz Leisering. Berlin et al.: Springer (first published in German 2001/2003).

Kaufmann, Franz-Xaver (2013c) The idea of social policy in Western societies: origins and diversity. International Journal of Social Quality 3,2: 16-40.

Kaufmann, Franz-Xaver (2015) Sozialstaat als Kultur. Berlin et al.: Springer VS. Korpi, Walter (2006) Power resources and employer-centered approaches in explanations of welfare states and varieties of capitalism: protagonists, consenters, and antagonists. World Politics 58,2: 167-206.

Kreckel, Reinhard (2008) Soziologie der sozialen Ungleichheit im globalen Kontext. In Transnationale Ungleichheitsforschung, eds. Michael Bayer, Gabriele Mordt, Sylvia Terpe, and Martin Winter. Frankfurt et al.: Campus, 23-69.

Lachenmann, Gudrun (1997) Informal security in Africa from a gender perspective. In Searching for security. Women's responses to economic transformations, eds. Isa Baud and Ines Smyth, London et al.: Routledge, 45-66.

Lavers, Tom and Sam Hickey (2016) Conceptualising the politics of social protection expansion in low income countries: the intersection of transnational ideas and domestic politics. International Journal of Social Welfare 25,4: 388-98.

Lavinas, Lena (2017) The takeover of social policy by financialization. The Brazilian paradox. New York: Palgrave Macmillan.

Lavinas, Lena (2018) The collateralization of social policy under financialized capitalism. Development and Change 49,2: 502-17.

Leisering, Lutz (2019) The global rise of social cash transfers. How states and international organizations constructed a new instrument for combating poverty. Oxford et al.: Oxford University Press.

Leisering, Lutz, Tao Liu, and Tobias ten Brink (2017) Synthesizing disparate ideas: how a Chinese model of social assistance was forged. Global Social Policy 17,3: 307-27.

Lepsius, M. Rainer (2017) Interests and ideas. Max Weber's allocation problem. In Max Weber and Institutional Theory, ed. Claus Wendt, Cham: Springer, 23-34.

Lessenich, Stephan (2003) Wohlfahrtsstaatliche Grundbegriffe. Historische und aktuelle Diskurse. Frankfurt and New York: Campus.

Lewis, Colin M., and Peter Lloyd-Sherlock (2009) Social policy and economic development in South America: an historical approach to social insurance. Economy and Society 38,1: 109-131. 
Lindert, Peter H. (2004a) Growing public. Social spending and economic growth since the eighteenth century. Volume 1, The story. Cambridge: Cambridge University Press.

Lindert, Peter H. (2004b) Growing public. Social spending and economic growth since the eighteenth century. Volume 2, Further evidence. Cambridge: Cambridge University Press.

Lindner, Ulrike (2014) The transfer of European social policy concepts to tropical Africa, 1900-50: the example of maternal and child welfare. Journal of Global History, 9: 208-231.

Luhmann, Niklas(1997)DieGesellschaftderGesellschaft.Frankfurta.M.:Suhrkamp. Lustick, Ian S. (1996) History, historiography, and political science: multiple historical records and the problem of selection bias. American Political Science Review 90,3: 605-18.

Mahoney, James and Kathleen Thelen (2015) Advances in comparative-historical analysis. Cambridge: Cambridge University Press.

Mares, Isabela and Matthew E. Carnes (2009) Social policy in developing countries. Annual Review of Political Science 12,1: 93-113.

Marshall, Thomas H. (1950) Citizenship and social class. In Thomas H. Marshall, Citizenship and social class and other essays, Cambridge: Cambridge University Press, 1-85.

Marshall, Thomas H. (1981a) Value problems of welfare-capitalism (with afterthought-The "hyphenated society"). In Thomas H. Marshall, The right to welfare and other essays, London et al.: Heinemann Educational Books, 104-36 (article first published 1972).

Marshall, Thomas H. (1981b) The right to welfare (with afterthought). In Thomas H. Marshall, The right to welfare and other essays, London et al.: Heinemann Educational Books, 83-103 (article first published 1965).

Meyer, John W. (2009) World society, eds. Georg Krücken, and Gili S. Drori, Oxford: Oxford University Press.

Midgley, James (1984) Social security, inequality, and the Third World. New York: John Wiley \& Sons.

Midgley, James (2013) Social protection in countries experiencing rapid economic growth. Goals and functions. In: Social protection, economic growth and social change. Goals, issues and trajectories in China, India, Brazil and South Africa, eds. Midgley, James and David Piachaud, Cheltenham/ Northampton: Edward Elgar, 7-25.

Midgley, James (2017) Social welfare for a global era. Thousand Oaks, CA: Sage. Midgley, James and David Piachaud (eds.) (2011) Colonialism and welfare. Social policy and the British imperial legacy. Cheltenham et al.: Edward Elgar. 
Midgley, James and David Piachaud (eds.) (2013) Social protection, economic growth and social change. Goals, issues and trajectories in China, India, Brazil and South Africa. Cheltenham/Northampton: Edward Elgar.

Noël, Alain (2006) The new global politics of poverty. Global Social Policy 6,3: 304-333.

Nullmeier, Frank (2000) Politische Theorie des Sozialstaats. Frankfurt et al.: Campus.

Nullmeier, Frank (2003) Anerkennung: Auf dem Weg zu einem kulturalen Sozialstaatsverständnis? In Wohlfahrtsstaatliche Grundbegriffe, ed. Stephan Lessenich, Frankfurt and New York: Campus.

Nullmeier, Frank (2006) Politikwissenschaft auf dem Weg zur Diskursanalyse. In Handbuch sozialwissenschaftliche Diskursanalyse, ed. Reiner Keller, Wiesbaden: VS, 287-313.

Offe, Claus (1984) Contradictions of the welfare state, ed. John Keane, London et al.: Hutchinson.

Öktem, Kerem Gabriel (2020) The welfare state as universal social security: a global analysis. Social Inclusion, 8,1, Thematic Issue 'Universalism' or 'Universalisms' in Social Policies?, 103-113.

Pankoke, Eckart (1970) Sociale Bewegung, sociale Frage, sociale Politik: Grundfragen der deutschen "Socialwissenschaft" im 19. Jahrhundert. Stuttgart: Klett.

Parsons, Talcott (1969) Politics and social structure. New York: Free Press et al.

Pereira, Carlos and Frederico Bertholini (2017) Beliefs or ideology: the imperative of social inclusion in Brazilian politics. Commonwealth \& Comparative Politics 55,3: 377-401.

Peters, B. Guy (2012) Institutional theory in political science, 3rd ed. New York: Continuum.

Petersen, Klaus and Daniel Béland (2014) Conclusion: comparative perspectives on social policy language, In Analysing social policy concepts and language. Comparative and transnational perspectives, ed. by Klaus Petersen and Daniel Béland. Bristol: Policy Press, 297-311.

Pfau-Effinger, Birgit (2005) Culture and welfare state policies: reflections on a complex interrelation. Journal of Social Policy 34,1: 1-18.

Pfau-Effinger, Birgit (2009) Wohlfahrtsstaatliche Politiken und ihre kulturellen Grundlagen. Österreichische Zeitschrift für Soziologie 34,3: 3-21.

Piachaud, David and James Midgley (2013) Conclusion: experiences, issues and future possibilities. In: Social protection, economic growth and social change. Goals, issues and trajectories in China, India, Brazil and South Africa, eds. 
Midgley, James and David Piachaud, Cheltenham/Northampton: Edward Elgar, 265-277.

Pinker, Robert (1971) Social theory and social policy, London: Heinemann.

Pinker, Robert (1979) The idea of welfare. London: Heinemann.

Rieger, Elmar and Stephan Leibfried (2004) Kultur versus Globalisierung. Sozialpolitische Theologie in Konfuzianismus und Christentum. Frankfurt am Main: Suhrkamp.

Rimlinger, Gaston V. (1971) Welfare policy and industrialization in Europe, America and Russia New York: Wiley.

Rudra, Nita (2007) Welfare states in developing countries: unique or universal?. Journal of Politics 69,2: 378-96.

Rueschemeyer, Dietrich and Theda Skocpol (eds.) (1996) States, social knowledge, and the origins of modern social policies. Princeton, NJ: Princeton University Press.

Schetsche, Michael (1996) Die Karriere sozialer Probleme, München: Oldenbourg.

Schmidt, Vivien A. (2008) Discursive institutionalism: the explanatory power of ideas and discourse. Annual Review of Political Science 11: 303-26.

Schmitt, Carina (2015) Social security development and the colonial legacy. World Development 70: 332-42.

Schmitt, Carina, Hanna Lierse, Herbert Obinger, and Laura Seelkopf (2015) The global emergence of social protection: Explaining social security legislation 1820-2013. Politics \& Society 43,4: 503-524.

Scruggs, Lyle (2007) Welfare state generosity across space and time. In Investigating welfare state change: the "dependent variable problem" in comparative analysis, eds. Jochen Clasen and Nico A. Siegel, Cheltenham: Edward Elgar, 133-65.

Seekings, Jeremy (2007a) "Pa's pension": the origins of non-contributory oldage pensions in late colonial Barbados. The Journal of Imperial and Commonwealth History 35,4: 529-47.

Seekings, Jeremy (2007b) Not a single white person should be allowed to go under: Swartgevaar and the origins of South Africa's welfare state, 1924-1929. The Journal of African History 48: 375-394.

Seekings, Jeremy (2008a) The ILO and Social Protection in the Global South, 1919-2005. ILO Century Project, Geneva: ILO.

Seekings, Jeremy (2008b) Welfare regimes and redistribution in the South. In Divide and deal. The politics of distribution in democracies, eds. Ian Shapiro, Peter A. Swenson, and Daniela Donno Panayides, New York: New York University Press, 19-42. 
Seekings, Jeremy (2011) British colonial policy, local politics, and the origins of the Mauritian welfare state, 1936-50. Journal of African History 52: 57-77.

Seekings, Jeremy (2012) Pathways to redistribution: The emerging politics of social assistance across the "Global South". Journal für Entwicklungspolitik 28,1: 14-34.

Seekings, Jeremy (2013) The Beveridge Report, the Colonial Office and welfare reform in British colonies. Mimeo.

Seekings, Jeremy (2016) A lean cow cannot climb out of the mud, but a good cattleman does not leave it to perish: The origins of a conservative welfare doctrine in Botswana under Seretse Khama, 1966-1980. CSSR Working Paper No. 387 (Centre for Social Science Research), University of Cape Town.

Shi, Shih-Jiunn (2017) Reviving the dragon: social ideas and social policy development in Modern China. Issues \& Studies 53,3: 1-25.

Singh, Prerna (2015a) How solidarity works for welfare. Subnationalism and social development in India. Cambridge: Cambridge University Press.

Singh, Prerna (2015b) Subnationalism and social development: a comparative analysis of Indian States. World Politics 67,3: 506-62.

Surender, Rebecca (2013) The role of historical contexts in shaping social policy in the Global South. In Social policy in a developing world, eds. Rebecca Surender and Robert Walker, Cheltenham et al.: Edward Elgar, 14-34.

Therborn, Göran (1995) European modernity and beyond: the trajectory of European societies 1945-2000. London: Sage.

Therborn, Göran (2019) Preface: the terrifying convergence of the three worlds of the "social question". In: The social question in the twenty-first century: a global view, eds. Breman, Jan, Kevan Harris, Ching Kwan Lee, and Marcel van der Linden, University of California Press, ix-xii.

Tillin, Louise and Jane Duckett (2017) The politics of social policy: welfare expansion in Brazil, China, India and South Africa in comparative perspective. Commonwealth \& Comparative Politics 55,3: 253-277.

Ullrich, Carsten G. (2003) Wohlfahrtsstaat und Wohlfahrtskultur. Zu den Perspektiven kultur- und wissenssoziologischer Sozialpolitikforschung. Mannheimer Zentrum für Europäische Sozialforschung, Working Paper no. 67, http://www.mzes.uni-mannheim.de/publications/wp/wp-67.pdf (retrieved 21 September 2017).

Ulriksen, Marianne S. (2012) Welfare policy expansion in Botswana and Mauritius: Explaining the causes of different welfare regime paths. Comparative Political Studies 45,12: 1483-509. 
UN (1948) Universal Declaration of Human Rights, UN General Assembly Resolution A/RES/217(III)A, 10 December 1948. New York: UN.

UN (1966) International Covenant on Economic, Social and Cultural Rights, UN General Assembly Resolution A/Res/21/2200, 16 December 1966. New York: UN.

UNRISD (2001) Social policy in a development context, UNRISD News No. 24. Geneva: UNRISD.

Uusitalo, Hannu (1984) Comparative research on the determinants of the welfare state: the state of the art. European Journal of Political Research 12: 403-422.

van Hulst, Merlijn and Dvora Yanow (2016) From policy "frames" to "framing": Theorizing a more dynamic, political approach. American Review of Public Administration 46,1: 91-112.

van Kersbergen, Kees (1995) Social capitalism: a study of Christian Democracy and the welfare state. London: Routledge.

van Kersbergen, Kees and Philip Manow (2009) Religion, class coalitions, and welfare states. Cambridge: Cambridge University Press.

van Oorschot, Wim, Michael Opielka, and Birgit Pfau-Effinger (2008) Culture and welfare state. Values and social policy in comparative perspective. Cheltenham and Northampton: Edward Elgar.

von Benda-Beckmann, Franz and Keebet von Benda-Beckmann (1994) Coping with insecurity. In Coping with insecurity. An "underall" perspective on social security in the Third World, eds. Franz von Benda-Beckmann, Keebet von Benda-Beckmann, and Hans Marks, Special Issue Focaal 22/23, Nijmegen: Focaal, 7-31.

von Gliszczynski, Moritz (2015) Cash transfers and basic social protection. Towards a development revolution? Basingstoke: Palgrave Macmillan.

von Gliszczynski, Moritz and Lutz Leisering (2016) Constructing new global models of social security: how international organizations defined the field of social cash transfers in the 2000s. Journal of Social Policy 45,2: 325-43.

Walker, Alan and Chack-Kie Wong (1996) Rethinking the Western construction of the welfare state. International Journal of Health Services 26,1: 67-92. Weber, Max (1978) Gesammelte Aufsätze zur Religionssoziologie, vol 1, 7th edn. J. C. B. Mohr, Tübingen.

Weible, Katrin (2016) What social cash transfer programmes do not do in middle income countries: identifying entitlement gaps in basic social protection. In United Nations System Staff College and Hertie School of Governance, eds., 
UN Reflection Series 2016: Development Cooperation, Policy Advice and Middle Income Countries, Berlin: Neopubli, 173-92.

Wood, Geof and Ian Gough (2006) A comparative welfare regime approach to global social policy. World Development 34,10: 1696-712.

World Bank (n.d.) World Development Indicators, available at https://datacatalog.worldbank.org/dataset/world-development-indicators, accessed 27 April 2020.

Zacher, Hans F. (2013) Social policy in the Federal Republic of Germany. The constitution of the social. German Social Policy 3, ed. Lutz Leisering. Berlin and Heidelberg: Springer.

Open Access This chapter is licensed under the terms of the Creative Commons Attribution 4.0 International License (http://creativecommons.org/licenses/ by/4.0/), which permits use, sharing, adaptation, distribution and reproduction in any medium or format, as long as you give appropriate credit to the original author(s) and the source, provide a link to the Creative Commons licence and indicate if changes were made.

The images or other third party material in this chapter are included in the chapter's Creative Commons licence, unless indicated otherwise in a credit line to the material. If material is not included in the chapter's Creative Commons licence and your intended use is not permitted by statutory regulation or exceeds the permitted use, you will need to obtain permission directly from the copyright holder. 